\title{
András Csaba
}

\section{Elkötelezett játékok}

\begin{abstract}
Absztrakt
A tanulmány a Molleindustria játékainak procedurális retorikáját vizsgálja, és arra a kérdésre keresi a választ, hogy a kisméretú és alacsony költségvetésú avantgárd videojátékok milyen módszerekkel közvetíthetnek politikai üzeneteket. Egy rövid elméleti bevezetô után a szöveg bemutatja a Molleindustria csoport központi alakjának szemléletét, majd egyes játékok szoros elemzésével mutat rá azokra a poétikai innovációkra, elidegenítô és kizökkentô stratégiákra, melyek segítségével a játékok megszüntetik magát a játékszituációt, és arra kényszerítik a befogadót, hogy a játék jeleinek játékvilágon kívüli referenciái felé forduljon.

\section{Szerzô}

András Csaba a PTE BTK Kerényi Károly Szakkollégiumának tanára, valamint a PTE BTK Modern Irodalomtörténeti és Irodalomelméleti Tanszékének óraadó oktatója. A Politikatörténeti Intézet Társadalomelméleti Múhelyének tagja. Ideológiák a trópusokon címú doktori disszertációját 2018-ban védte meg a PTE BTK Irodalomtudományi Doktori Iskolájában. İrásai a Literatura, a Jelenkor, a Médiakutató, a Filológiai közlöny és a vajdasági Híd folyóiratokban, valamint a kolozsvári a szem portálon jelentek meg. A retorikaelmélet, az ideológiakritika, a kritikai kultúrakutatás, a filmtudomány és a ludológia területén folytat kutatásokat.

E-mail: andrascsab@gmail.com
\end{abstract}

https://doi.org/10.31176/apertura.2019.14.2.6 


\section{András Csaba}

\section{Elkötelezett játékok}

\section{Tutorial - Politikai játékok}

A Monopoly (Parker Borthers, 1935) legfontosabb elôzményének tekintett The Landlord's Game (Elizabeth J. Phillips, 1904) címú táblajáték azzal a céllal született, hogy felhívja a játékosok figyelmét az uralkodó gazdasági rendszer igazságtalanságára. Az Sufragetto (1909) nevú társasjátékban az egyik játékosnak a rendôrökkel szemben felsorakozott szüfrazsetteket kell irányítania, és át kell törnie a rendőrsorfalat, mielôtt figurái a kórházba vagy a börtönbe kerülnének. A Class Struggle (Bertell Ollmann, 1978) címú táblajáték kezdetén a játékosok kockadobással sorsolják ki, hogy melyikük szülessen „munkásnak” vagy „kapitalistának”, és ennek megfelelóen a játék során melyik csoport oldalán kell majd megnyerniük az osztályharcot. Ezek a játékok a baloldali társasjátékok csaknem teljesen elfeledett hagyományának legfontosabb darabjai, és elsôsorban az köti össze ôket, hogy mindegyik vállalt célja politikai üzenetek közvetítése.

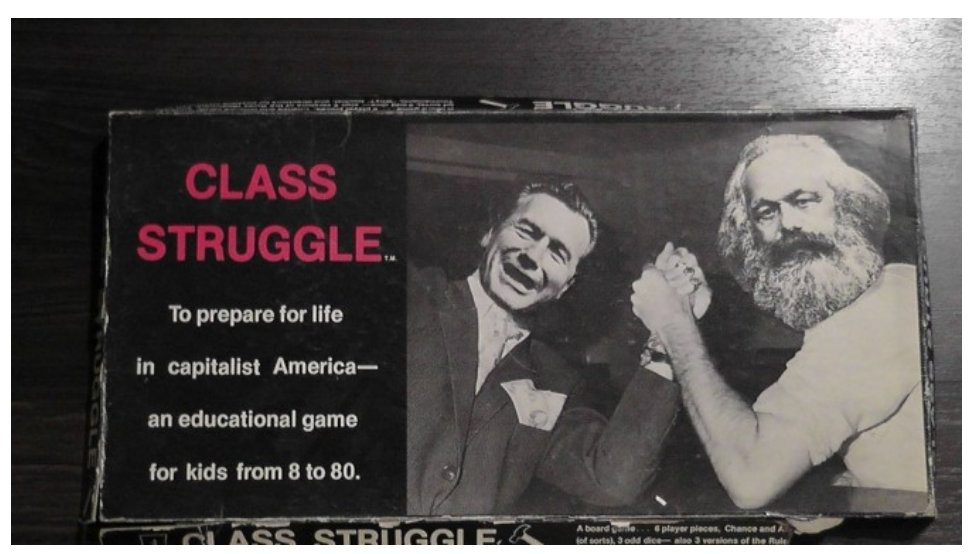

A Class Struggle (Bertell Ollmann, 1978) címú táblajáték doboza.

Noha napjainkban megfigyelhető a táblajátékok reneszánsza, a játékok területét mára egyértelmúen a videojátékok uralják. A videojátékok szisztematikus vizsgálatával foglalkozó tudományterület, a - magyarul gyakran „ludológiaként” emlegetett - game studies területén a játékok ideológiakritikai szempontú vizsgálatának komoly hagyományai vannak. ${ }^{[1]}$ A ludológia elsố korszakában a videojátékot mint médiumot próbálták ebből a szempontból leírni, ez a közelítésmód határozza meg - többek között - Marsha Kinder ${ }^{[2]}$ és Eugene F. Provenzo ${ }^{[3]}$ 
vonatkozó szövegeit. Késôbb fokozatosan a játékok egyes elemeinek vizsgálatára került a hangsúly. Utóbbi kategóriába sorolhatjuk a feminista ludológus, Anita Sarkeesian munkásságát is, aki a Tropes vs. Women in Video Games címú videosorozatában a nôi nem játékvilágbeli reprezentációjának hagyományát elemzi. ${ }^{[4]}$

A számítógépes játékok ideológiakritikai szempontú vizsgálatához a legkidolgozottabb keretet Ian Bogost írásaiban találjuk. Az összehasonlító irodalomtudományi képzettséggel és széleskörú ideológiaelméleti tudással rendelkező Bogost a videojátékok olyan elméletét hozta létre, mely a játék világának ideologikus elemein túl a játék múködésmódjából (vagyis a játékmechanizmusból) adódó ideologikus tartalmakkal is számol. Bogost központi fogalma a procedurális retorika, ${ }^{\left[{ }^{5]}\right.}$ ennek meghatározásakor a proceduralitás alatt a szabályok által meghatározott folyamatokat érti; a retorika fogalmát arisztotelészi értelemben, a meggyôzés módjaként használja; az általa létrehozott retorikatípust pedig a szóbeli, az írásbeli és a vizuális kommunikáció retorikájával szemben határozza meg. Bogost szerint a játékok az általuk elvégeztetett gyakorlatok segítségével győznek meg minket különböző tartalmakról, vagy ezeknek a folyamatoknak a segítségével mutatnak rá egyes rendszerek múködésének logikájára. ${ }^{[6]}$ A procedurális retorika legtömörebb definíciója szerint „a meggyôzésre használt folyamatok gyakorlata”, „folyamatokon keresztüli érvelés". ${ }^{[7]}$

Mindezek alapján jól látható, hogy a game studies ideológiakritikai ága kimondottan erôs; ráadásul a fentiek mellett számos további, alaposan kimunkált érvrendszer áll a rendelkezésünkre, ha a játékipar és a mainstream videojátékok bírálata a célunk. ${ }^{[8]}$ Ezzel szemben feltûnố az olyan értelmezések hiánya, melyek a játékok ideologikus tartalmainak leleplezése helyett azokra a játékokra koncentrálnának, melyek - a korábban említett táblajátékokhoz hasonlóan - explicit politikai üzenetet közvetítenek; társadalmi, kulturális és gazdasági folyamatokat próbálnak reflektálttá tenni, és maguk is ideológiakritikai munkát végeznek. Az ilyen baloldali (szocialista, anarchista, szindikalista, szociáldemokrata stb.) játékokat nevezem - Jean-Paul Sartre „elkötelezett irodalom" [litterature engagée] terminusa nyomán ${ }^{[9]}$ - elkötelezett játékoknak. E játékok átfogó elméletének kidolgozásával mindeddig kevesen próbálkoztak, ${ }^{[10]}$ a játékok politikai aspektusa a legtöbb szakmunkában csak mint mellékes tényezô kerül elô.

Tanulmányom épp ezért kettôs céllal született. Egyrészt hozzá szeretnék járulni annak a tudományos diskurzusnak a szélesedéséhez (és hazai kialakulásához), mely a videojátékokban rejlô politikai lehetôségeket vizsgálja, és azokat a módszereket azonosítja, melyek segítségével e játékok - a médiumspecifikus sajátosságok és a játékokhoz kapcsolódó befogadási mód korlátozó ereje ellenére - politikai üzeneteket közvetítenek. Másrészt ez az írás nem pusztán a téma kutatóihoz és a kritikai kultúrakutatás iránt érdeklődókhöz szól, hanem azokhoz is, akik valamilyen formában részt vesznek (vagy vehetnek) a játékok létrehozásában: a tanulmány komoly eredménye volna, ha inspirációval szolgálhatna azoknak, akik be akarnak lépni az elkötelezett játékok létrehozóinak körébe.

Egy ekkora méretű szöveg természetesen nem foghatja át a politikai játékok teljes területét, ezért a 
vizsgálat fókuszát az utóbbiaknak egy speciális csoportjára szúkítettem. Nem foglalkozom a színházi társasjátékokkal, ${ }^{[11]} \mathrm{a}$ pártpolitikai játékokkal, ${ }^{[12]}$ és azokkal - az elsôre játéknak tûnô ismeretterjesztô szimulációkkal sem, ${ }^{[13]}$ melyek látszólagos játékszerúségük ellenére sokkal inkább az ergodikus irodalom kategóriájába sorolhatók. ${ }^{[14]}$ Az általam vizsgált játékok több bevett játékkritikai kategória metszéspontjában helyezkednek el: többségük böngészőfelületen játszható ( flash games), alkalmi (casual games), nagy piaci szereplôktől független (indie games), komoly (serious games), gyakran múvészi intenciókkal rendelkezô (art/arthouse games) politikai játék (political games). Emellett ezek a játékok abba a csoportba tartoznak, melyet Brian Schrank a „mainstream” játékokkal szemben avantgárd videojátékoknak nevez, ${ }^{[15]}$ vagyis melyek a médium lehetôségeinek határait feszegetve megpróbálják újradefiniálni magát a videojátékot.

Vizsgálati területnek az olasz játékgyártó kollektíva, a Molleindustria játékait választottam. Ez semmi esetre sem tekinthetô szokatlan döntésnek: a játékok ideológiai/politikai aspektusával foglalkozó kutatók rendszeresen elemzik a csoport alkotásait, noha jellemzóen csak egy-egy játékukat emelik ki. ${ }^{[16]}$ Tanulmányom fó kérdése, hogy a Molleindustria csoport játékai milyen stratégiák segítségével közvetítenek politikai üzeneteket, különös tekintettel 2008-as „ökojátékukra”, az Oiligarchyra. Ennek vizsgálatához a bevezetốt követô alfejezetben két, egymástól nehezen elválasztható interakciós mód vagy befogadási forma, a játék és az értelmezés viszonyának pontosabb meghatározására és a játékok referenciális jellegének vizsgálatára vállalkozom. A harmadik rész általános képet ad a Molleindustria tevékenységéról és a csoport központi figurája, Paolo Pedercini poétikai és politikai programjáról. A negyedik alfejezetben több játék értelmezésén keresztül bemutatom a Molleindustria alkotásainak fố retorikai jellegzetességeit, az ötödikben a csoport eddigi legsikeresebb játékának alapos elemzésével szemléltetem a politikai procedurális játékretorikák mindeddig legtermékenyebbnek túnô irányát. Végül a hatodik részben összefoglalom és tágabb kontextusba helyezem a tanulmány korábbi megállapításait.

\section{Demo - Játék, értelmezés, referencialitás}

A játékosok értelmezői tevékenységének megragadáshoz érdemes a játékosi befogadói magatartás aktivitásjellegéból kiindulnunk. Ennek vizsgálatával a nézés és a tett, az értelmezés és a cselekvés, az aktivitás és a passzivitás egymással szembeállított fogalmainak terepére érünk, melyet Jacques Rancière elemez A felszabadult nézố címú kötetében. ${ }^{[17]}$ Rancière szerint a színház 20. századi „reformerei” azt várják a nézôtôl, hogy átlépje „a passzivitás és aktivitás közötti szakadékot”, [18] miközben ugyanezek az értelmezôk az élet más területein a „látás és a tevés” hierarchiáját egészen máshogyan gondolják el. ${ }^{[19]}$ Miközben a fizikai munkás gyakorlati aktivitása jellemzôen sokkal kevesebbre becsült tevékenység, mint az értelmiségi reflexív szemlélódése, a színház terepén egyértelmúen a résztvevô aktivitásának felértékelését figyelhetjük meg a „nézô” passzivitásának leértékelése mellett. Rancière ennek kapcsán azt írja:

Mi más okból bélyegezhetnénk a helyén ülô nézốt inaktívnak, ha nem aktív és passzív 
radikális ellentéte miatt? Miért azonosítanánk a nézést a passzivitással, ha nem azon előfeltevés miatt, hogy nézni annyi, mint képben és látszatban tetszelegni, figyelmen kívül hagyva a kép mögötti igazságot és a színházon kívüli valóságot? Miért hasonlítanánk a hallást a passzivitással, ha nem az előítélet miatt, hogy a beszéd a cselekvés ellentéte? Ezek az ellentétpárok - nézés/tudás, látszat/valóság, aktivitás/passzivitás - egészen mások, mintsem jól meghatározott fogalmak logikai szembeállításai. [20]

Rancière azzal folytatja, hogy az értelmezést is cselekvésnek kell tekintenünk, és a nézó már azzal az elôadás „aktív” részesévé válik, hogy „megfigyel, kiemel, összevet, értelmez”. [21]

Ha a számítógépes játékok kulturális megítélését $A$ felszabadult nézóben olvasható érvelés alapján vesszük szemügyre, akkor arra figyelhetünk fel, hogy míg a színház esetében a nézői „részvétel” és „aktivitás” kitüntetett és magasan értékelt befogadói magatartás, addig a játékok megítélésekor kifejezetten ritkán merül fel ez a kritikai szempont a maga pozitív hozadékaival. Rancière-nek ugyanakkor igaza van abban, hogy az aktivitás-passzivitás fogalompárhoz kapcsolódó előfeltevéseinket kritikával kell kezelnünk. Éppen ezért azt érdemes alaposabban szemügyre vennünk, hogy a játékos „aktivitása” és a Rancière által a cselekvés rangjára emelt „értelmezés” milyen viszonyban áll egymással.

A kérdés vizsgálatához jó kiindulópont a norvég ludológus, Espen J. Aarseth Müfaji zavar: a narrativizmus és a szimuláció múvészete címú tanulmánya. Aarseth szerint „kérdéses, hogy az esztétikai volna a legrelevánsabb perspektívája” a játékok vizsgálatának, ${ }^{[22]}$ de ha mégis ebból az irányból közelítünk, akkor arra jutunk, hogy „a játékoknak a valódi esztétikai értéke sokkal inkább a szabályrendszerükön, és jóval kevésbé a játékviláguk elgondolásán áll vagy bukik”. ${ }^{[23]}$ Tehát bár a szúk értelemben vett, a játékok vizuális sajátosságaira koncentráló „esztétikai” szempont sem elhanyagolható, de - azt, hogy a sakk mennyire ,jó” játék, csak kis mértékben határozza meg a

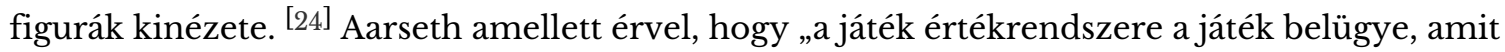
egyértelmúen a szabályok határoznak meg”. [25]

Ezt az értelmezést tovább radikalizálhatjuk: nemcsak arról van szó, hogy a játékok vizsgálatának nem feltétlenül az „esztétikai” a legrelevánsabb perspektívája, hanem arról is, hogy a számítógépes játékok befogadási módja annyira eltér a képek, a szövegek vagy a filmek befogadásának módjától, hogy maguknak a bennük szereplő jeleknek a játékvilágon túli jelentése válik kevésbé hangsúlyossá. Nincs különösebb jelentősége annak, hogy Super Mario (Super Mario Bros., Nintendo, 1985) miért egy olasz vízvezeték-szerelô, ${ }^{[26]}$ vagy hogy hogyan kerülnek a világába sétáló gombák. A játék elemeinek egymáshoz való viszonya fontosabb annál, amit ezek az elemek ,jelölnek”.

Super Mario karakterét szemlélve felmerül a kérdés, hogy a játékosokat miért nem zavarja a játékvilág jeleinek ez a szokatlan kombinációja. Erre a kérdésre pontos választ ad Kiss Gábor Zoltán egyik tanulmányának részlete:

A hagyományos és a digitális média közötti [...] még alapvetôbb különbség abban áll, hogy míg a hagyományos médiát a jelölők értelmezésbeli szinergiája hatja át, addig az újat a mú 
(az iteratív rendszer) és a felhasználó mérnöki képességei közötti kapcsolat mozgatja. A különbséget úgy is kifejezhetjük, hogy míg a hagyományos média [...] értelmezói tevékenységre késztet, addig az iteratív média esetében a felhasználó [...] egy gépezetet üzemeltet [27]

Alapvetố különbség van tehát a játékok és a hagyományos reprezentációs médiumok által felkínált befogadói pozíciók között. A játékok jelekból álló gépezetek múködtetését várják el a játékostól, miközben más mediális formákhoz mérten kevésbé - de legalábbis: másként - értelmeztetik velük az ábrázolt jeleket. Természetesen a játékos is értelmezői munkát végez, amikor felismeri a játék szabályait, megérti annak belsô összefüggéseit, és felhasználja a korábbi tapasztalataiból eredô tudását. Ebben az értelmezői munkában ugyanakkor a játékost elsôsorban a jel funkciója érdekli a gépezetben, vagyis az, hogy hogyan hat egy jel más jelekre a játékon belül. A játékos érdeklődésének fókuszában nem az áll, hogy mit jelent egy jel, hanem az, hogy hogyan viselkedik. Éppen ezért a játék a valóságreferencia szempontjából kimondottan zárt forma.

Az a tény, hogy a játékok jeleit jellemzően kevésbé (vagy kevésbé tudatosan) kapcsoljuk a játékon kívüli valósághoz, és ezért a játékosok ritkábban vélik úgy, hogy egy játék „állít valamit a világról”, vagy „szól valamiról”, nagyban meghatározza a médium lehetôségeit arra, hogy politikai üzeneteket közvetítsen. Ebból a szempontból tanulságos a Tetris (Alekszej Pazsitnov, 1984) kapcsán kialakult elméleti vita, mely a ludológiai szakirodalmak által talán legtöbbet idézett teoretikus konfliktus. [28]

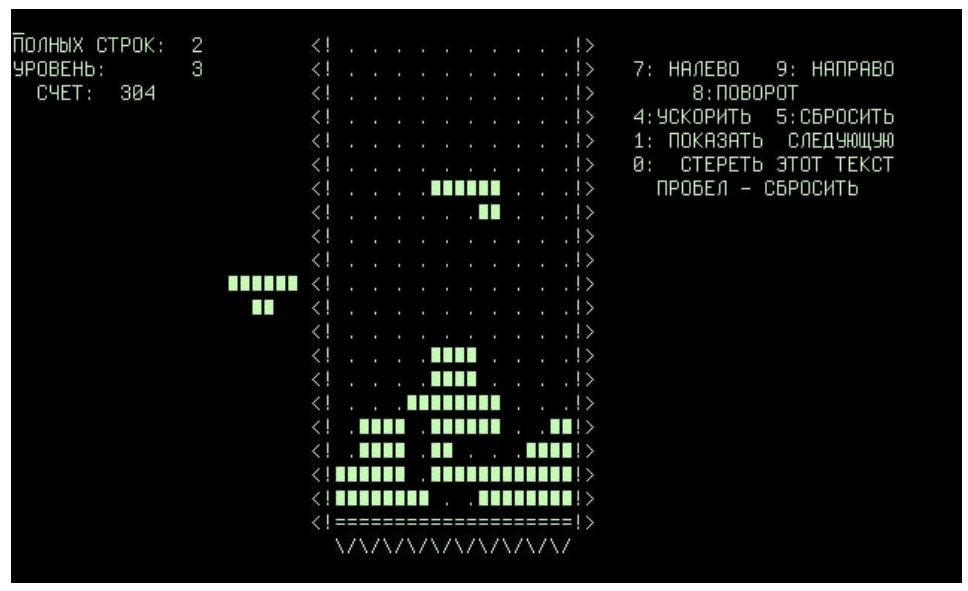

Tetris (Alekszej Pazsitnov, 1984)

Gonzalo Frasca a reprezentáció-szimuláció fogalompár alkalmazásával definiálja a számítógépes játékok és a reprezentációs médiumok (szöveg, kép, film) különbségét, értelmezésében „a hagyományos médiumok reprezentációsak, és nem szimulációsak". ${ }^{[29]}$ A szimulációs és a reprezentációs médiumok elkülönítését Frasca a repülógép-szimulátorok példáján keresztül mutatja be: 
Egy repülőgép fényképe információt tartalmaz annak alakjáról és színérôl, de nem fog repülni vagy lezuhanni. Egy repülôgép-szimulátor vagy egy egyszerú játékrepülố nem csupán jel, hanem olyan gép, ami olyan szabályok szerint generál jeleket, amelyek modellezik a valódi repülőgép viselkedését. [30]

Frasca szerint „szimulálni annyit tesz, mint modellezni egy (forrás)rendszert egy más rendszeren keresztül, amely (valamely szemlélố számára) átveszi az eredeti rendszer viselkedési mintáját”. [31] A forrásrendszer azonosítása viszont sokszor nem könnyú feladat, ${ }^{[32]}$ és maga Frasca is elismeri, hogy számos játék kivételt képez. Ilyen például szerinte a Tetris, amely „nem valós forrásrendszeren alapul: nem szimulálja a valóságot, pusztán egy absztrakt környezetet teremt”. [33] Ezzel ellentétes Janet Murray álláspontja, aki a Hamlet on the Holodeck címú kötetében felismerni véli a Tetris forrásrendszerét, amikor azt írja:

A Tetris tökéletesen színre viszi a 90-es évek amerikai állampolgárainak agyondolgoztatott életét, a feladatok folyamatos bombázását, amelyek a figyelmünket igénylik, melyeket valahogy bele kell illesztenünk túlzsúfolt napirendünkbe, és le kell takarítanunk az asztalainkról, hogy helyet biztosítsunk a következô támadásnak. [34]

A Tetrist az Orosz Tudományos Akadémia munkatársaként dolgozó Alekszej Pazsitnov hozta létre 1984-ben, még jóval 1986-os amerikai egyesült államokbeli feltúnése elôtt. E tény alapján Murray áláspontja történeti tévedésnek tûnhet, a ludológusok ugyanakkor elsôsorban nem erre helyezik a hangsúlyt bírálataikban. Murray értelmezésének leghevesebb kritikusa Markku Eskelinen, aki számon kéri a szerzốn azt az „interpretatív erôszakot”, mely a játékot mindenképpen valamilyen megalapozó háttértörténethez, valós referenciához köti:

Épp ilyen messze járna a lényegtôl az, aki a sakkot a tökéletes amerikai játékként értelmezné, mivel a hierarchikusan szervezôdô fekete és fehér közösségek küzdelmét ábrázolja, a nemek nem egyenlôk, a sérült figurák pedig nem részesülnek egészségügyi ellátásban. [...] Ahelyett, hogy a tényleges játékot vizsgálná, Murray a feltételezett tartalmát próbálja értelmezni, jobban mondva rávetíti a kedvenc tartalmát, következésképpen semmit sem tudunk meg azokról a jellemzôkrôl, melyek a Tetrist játékká teszik. [35]

A fenti részleteket feldolgozó ludológiai szakirodalom ezeket elsôsorban a ludológia-narratológia vita viszonylatában tárgyalja, vagyis azon nézetkülönbség egyik epizódjaként, mely a játékok „történetszerüsége” körül folyik. Ebból a szempontból Murray és Eskelinen ellentéte az elbeszéléselmélet felôl érkezố tudományos kolonialista és az azzal szembeszálló, csakis a játékok immanens vizsgálatában érdekelt ludológus konfliktusa.

A szövegek születésekor minden bizonnyal ez volt a hozzászólások releváns kontextusa, szempontomból ugyanakkor a nézetkülönbség inkább a játék és annak referenciája, vagyis a játék 
és játékhoz köthetô valós rendszer összekapcsolásának problémáira világít rá. Murray értelmezése szubjektívnek tetszhet az erôsen formalista indíttatású, a játékok játékszerúségére koncentráló ludológusoknak, miközben talán kevésbé tûnne elrugaszkodottnak a kultúratudományok képviselôinek. ${ }^{[36]}$ A ludológusok ugyanakkor nemcsak formalista közelítésmódjukból és az immanens vizsgálat melletti elkötelezettségükbool adódóan kritikusak a fenti értelmezéssel, hanem mert az „átlagos játékos” befogadási módját tekintik irányadónak. ${ }^{[37]} \mathrm{Az}$ „átlagos játékos” pedig ritkán értelmezi a Tetrist a kapitalista gépezetben a feladatokkal sziszüphoszi versenyt futó átlagember helyzetének allegóriájaként. Murray értelmezése ellen éppen az szól, hogy a játékosok nem így értelmezik a játékokat - a játéktudomány szempontjából pedig éppen az a fontos, hogy miért nem.

A játék (a szimuláció) és a játék referenciájának (a szimulált valós rendszer) összekapcsolása tehát nem mindig könnyú, ráadásul a játékban érvényesülni akaró játékos sokkal kevesebb erôfeszítést tesz ennek a referenciának a felismerésére, mint ahogy azt más médiumok esetében tapasztaljuk. Éppen ezért különbséget kell tennünk a játékok között az absztrakció foka alapján, vagyis aszerint, hogy a játék szimulációját mekkora értelmezői erőfeszítés segítségével köthetjük a bennük szimulált, valós rendszerekhez.

A számítógépes játékok kapcsán az ideológiakritika fố vizsgálati terepét azok a játékok jelentik, melyek nagy mimetikus hatásfokkal modelleznek komplex társadalmi rendszereket. Ezek az elemzések rámutatnak, hogy a játékvilágokban a nôi karakter általában mellékes, „nem játszható” esztétikai objektum; ${ }^{[38]}$ hogy a Civilization sorozat játékai térben és idôben is univerzálisnak tüntetik fel a 19. századi európai természettudományos szemléletet és a nyugati hatalmak

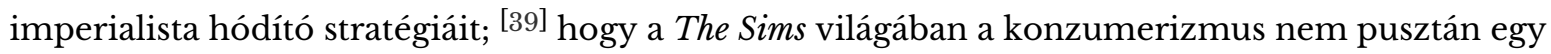
választható viselkedésmód, hanem a társadalmi érvényesülés és a „boldogság” egyetlen lehetôsége; ${ }^{[40]}$ hogy a Prison Architect megerôsítheti az amerikai büntetés-végrehajtási rendszer nehezen igazolható előfeltevéseit; ${ }^{[41]}$ vagy hogy bármilyen formabontó várost is tervezzünk a SimCity sorozat játékai által nekünk kijelölt földterületen, a három fố társadalmi csoport („low”, „medium” és „high wealth”) közötti gazdasági különbség semmilyen módszerrel sem számolható fel. ${ }^{[42]}$ Ezek az értelmezések fóképp arra koncentrálnak, hogy egy játék rendszere milyen programozott szabályok segítségével ragadja meg a valós folyamatokat, vagyis hogy a szükségszerú leegyszerúsítés és leszúkítés során milyen mechanizmusokat ítél relevánsnak, és a szelekció során milyen lehetôségeket mulaszt el felkínálni, melyek a valóságban felmerülhetnének. 


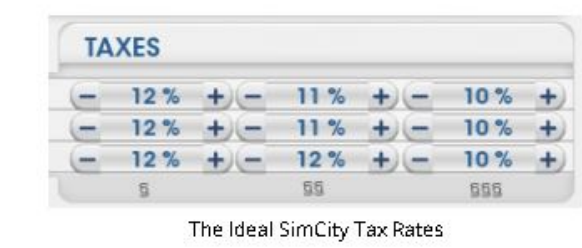

A SimCity (Maxis, 1985) ideális adókulcsai a

SimCity Planning Guide szerint.

Mivel a játékos a jeleket a játékon belüli funkciójuk alapján értelmezi, és azok referenciális jelentése helyett a játékon belüli hatásukra fókuszál, ezért a komplex folyamatokat modellezô játékok különösen alkalmasak bizonyos ideológiai tartalmak implicit közvetítésére, amennyiben megerôsítik a játékost abban, hogy bizonyos szabályszerúségek és tendenciák alapvetôek, „természetesek” és a történelmi körülményektôl függetlenül állandóak. Ha Roland Barthes napjainkban írná meg a Mitológiák esszéit, ${ }^{[43]}$ akkor a mainstream videojátékok világát valószínúleg éppen annyira gyümölcsözô vizsgálati terepnek találná, mint a reklámplakátok, a pankráció vagy a hollywoodi történelmi filmek alkotta kulturális mezôt: a mainstream számítógépes játékok naturalizálják a bennük megjelenített rendszereket és gyakorlatokat. [44] Mindez többnyire nem szándékos, nem tudatos ideológiai manipuláció (vagyis feltételezhetjük, hogy az alkotók általában „nem tudják, de teszik”), és fóképp abból adódik, hogy a játékok a fennálló társadalmi berendezkedést modellezik, és nem azt, ami ezen túl elgondolható. Ezek a játékok tehát képesek arra, hogy bizonyos társadalmi minták megismétlésével szükségszerúnek, magától értetődônek és természetesnek tüntessenek fel olyasmit, ami nem az.

Másrészrôl azokat a játékokat, melyek kevésbé komplexek és „valósághúek”, melyek kevesebb szabállyal dolgoznak, és amelyeket nehezebb valós referenciához kötni, a korábban bemutatott tulajdonságaik kimondottan alkalmatlanná teszik arra, hogy különbözô ideológiai/politikai tartalmakat explicit módon közvetítsenek vagy reflektálttá tegyenek. Jól illusztrálja ezt a Murray Tetris-értelmezését bíráló kritika, és jó példa Eskelinnen korábban idézett sakkértelmezése is: a játékok politikai „üzenetének” dekódolása meghökkentônek tûnik és gyanakvást ébreszt.

Kapcsolódó példaként érdemes szemügyre vennünk a Monopoly nevú táblajáték alakulástörténetét. [ ${ }^{45]}$ Amikor a világ egyik legsikeresebb társasjátékát 1934-ben létrehozta és 1935-ben kiadta a Parker Brothers vállalat, az Egyesült Államokban már számos, a Monopolyhoz nagyon hasonló táblajáték létezett. A Monopoly legfontosabb előzményét 1906-ban készítette el Elizabeth J. Phillips, akinek az volt a célja a játékkal, hogy Henry George amerikai politikus és közgazdász „single tax theory” javaslatát illusztrálja vele, vagyis hogy az ingatlanmonopóliumok kialakulásának veszélyére irányítsa a figyelmet. A Monopoly létrehozói csak kis átalakításokat végeztek a játékon, mely nem változtatott a játékba kódolt strukturális kritikán. Ennek ellenére a legtöbb játékos semmiféle politikai üzenetet sem tulajdonít a Monopolynak, vagy legalábbis jóval kevésbé ismeri fel a játék 
„állítását”, mintha egy szöveget olvasna, amely a játék által eredetileg kritizált folyamatokat tematizálja. ${ }^{[46]}$ Emellett ha a játékosok felismerik a játék témáját, akkor sem biztos, hogy azonosítják benne a kritikai intenciót: a „keleti blokk” nagy részében, vagyis a létezô szocializmus országainak többségében a Monopoly a kapitalizmus kritikája helyett a kapitalizmus szimbólumává vált; Fidel Castro egyik elsô intézkedése volt hatalomra jutása után, hogy betiltotta a játékot Kubában; és a mai napig tilos a játék terjesztése Kínában. ${ }^{[47] ~ U ́ g y ~ t u ̂ n i k, ~ h o g y ~ m e ́ g ~ a ~ j a ́ t e ́ k o t ~}$ értelmezni akaró játékosok számára sem volt egyértelmú, hogy a Monopoly a kapitalizmus mellett áll (bárkiból lehet dúsgazdag tókés), vagy pedig épp a kapitalizmus ellen emel szót (idôvel minden vagyon kevesek kezében összpontosul), esetleg egyiket sem teszi.

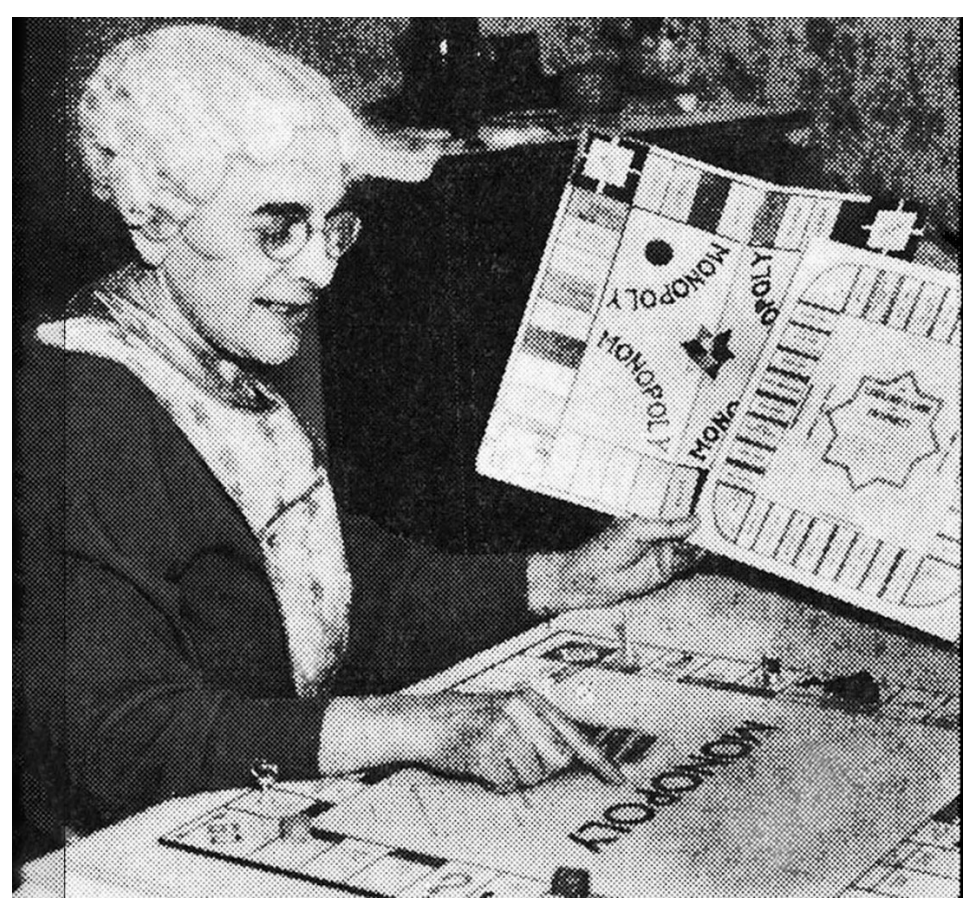

Elizabeth J. Phillips a washingtoni Evening Star 1936-os felvételén, kezében a The Landlord's Game és a Monopoly tábláival.

Ahhoz tehát, hogy egy kisebb, kevésbé mimetikus játék explicit ideológiai üzenetet közvetíthessen, valamiképpen meg kell birkóznia azzal az akadállyal, hogy a játékos nem a játék „mondandójára” vagy „üzenetére” kíváncsi, pusztán érvényesülni akar a játék keretei között. Valamilyen radikális poétikai innováció segítségével ki kell zökkentenie a játékost a megszokott befogadói pozíciójából. A formabontó, avantgárd játékok ilyen megoldásokkal kísérleteznek. A következôkben ilyen formabontó kísérletekrôl, innovatív poétikai megoldásokról lesz szó a Molleindustria játékai esetében. 


\section{Credits - Paolo Pedercini és a Molleindustria}

Bár a Molleindustria játékai a felhasználók, a kritikusok és a játékkutatók körében egyaránt ismertek és elismertek, magáról a csoportról - ha egyáltalán valóban „csoportról” van szó - viszonylag keveset tudunk. Honlapjuk, a Molleindustria.org 2003 decemberében indult egy kiáltvánnyal, [48] melynek bevezetôje még egyes szám elsô személyben fogalmaz, utolsó része viszont - a honlapon olvasható önmeghatározáshoz hasonlóan ${ }^{[49]}$ - már többes szám elsố személyben szól. A Molleindustria nevében kizárólag az olasz származású Paolo Pedercini nyilatkozik, aki ilyenkor többnyire úgy beszél a játékokról, mintha jórészt egyedül hozta volna létre óket. Pedercini a vele készült riportokban nem sok információt oszt meg magáról a Molleindustriáról, szívesebben beszél a játékaikról és az alapelveikrôl. Sajtóreprezentációjuk alapján úgy tûnik, hogy a Molleindustria gyakorlatilag Paolo Pedercini egyszemélyes vállalkozása, melyhez egy-egy játék létrehozására alkalmilag mások is társulnak.

Maga Pedercini jelenleg a Carnegie Mellon University múvészeti tanszékének oktatója. Kurzusain az internetes avantgárdról és ellenkultúráról, a hacker-kultúráról, a „láthatatlan web” világáról, internetes kiáltványokról, a „critical game studies” és a kísérleti játék-design témaköreirôl tart előadásokat, szemináriumokat és múhelyeket, de szervezett már a Disney és a Pixar vizuális hegemóniájával szemben meghatározott design-kurzust is. ${ }^{[50]}$ Pedercini tehát nem pusztán alkotó, hanem politikai aktivista, valamint a ludológia területén jártas, határozott kritikai állásponttal rendelkezô kutató is, a game studies konferenciák gyakori és népszerú elôadója. [51]

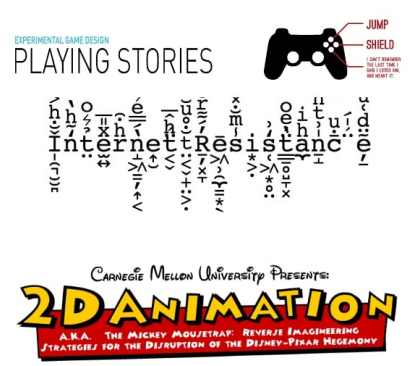

Paolo Pedercini kurzuskinálatának egy része saját honlapján (mycours.es).

Saját alkotói szemléletének alapja a játékipar bírálata. Pedercini gyakran kritizálja a játékok „mainstream” hagyományát, utóbbi már a Molleindustria Manifestóban is hangsúlyos:

A Molleindustria nem szereti a videojátékokat, épp ez az oka, hogy létrehozza ôket. Mikor az újhullám kritikusai megunták, hogy a Cahiers du Cinema hasábjain püföljék a filmipart, elkezdték létrehozni a saját filmjeiket, a rendelkezésükre álló korlátozott eszközök 
felhasználásával. Ez a célunk [...]. Olyan teret hozunk létre, melyben az elméleti és a gyakorlati kritika kéz a kézben jár. ${ }^{52]}$

Pedercini a vele készült riportokban a kortárs játékipart rendszeresen a filmgyártás „hollywoodi paradigmájához" hasonlítja, bírálva ezzel annak innovációktól mentes, önismétló jellegét. Szerinte a játékok számos kreatív lehetôséget kínálnak, mivel „könnyü velük leírni komplex gazdasági és társadalmi helyzeteket”, és könnyebben is közvetítik ezeket a tartalmakat, mint a korábbi médiumok, mivel „videojátékot játszani nagyjából ugyanaz, mint megérteni a mechanikáját”. [53] Ennek kapcsán említi Pedercini Ted Friedman a game studies területén mára szállóigévé vált gondolatát, ${ }^{[54]}$ miszerint Marx $A$ tôkéjéból könnyebb lenne számítógépes játékot készíteni, mint filmet. ${ }^{[55]}$

A fenti, a médium lehetôségeire vonatkozó megállapításokból jól látható, hogy Pedercini a játékok alapvetố hatásmechanizmusaival kapcsolatban osztja Ian Bogost álláspontját, ami már csak azért sem meglepó, mivel Bogost ezt az álláspontot jórészt épp a Molleindustria játékaira alapozva dolgozta ki. ${ }^{[56]}$ Pedercini ugyanakkor továbbmegy a játékok fô irányvonalának bírálatában, mikor egy általános játékosi attitúdöt tesz kritikája tárgyává:

Ahogyan mozgó platformok között ugrál, hordókat robbant fel a megfelelô idôben, felizzó drágaköveket gyújt össze, kincsesládákat keres, fejlövéssel szerez pontot, megostromol egy úrlénybázist, tökéletesíti útvonalának ívét egy versenyen, fejleszti a fegyvereit, tökéletes négyzetekre oszt egy földterületet, extra életet szerez, társat toboroz magának, felméri a kibányászható nyersanyagokat, befektet egy új infrastruktúrába, meggyôz egy másik karaktert, a helyére rak egy zuhanó tömböt; ahogyan a próbálkozásaiból tanul, nyer, veszít; szóval ahogyan ezt mind végrehajtja, bármely játékostársam rádöbbenhet, hogy minden tettére egy sajátos gondolkodás- és cselekvésmód vonatkozik. Ha a maguk roppant változatossága ellenére a számítógépes játékokban van valami közös, akkor az a hatékonyság [efficiency] és az irányítás [control] kikényszerítése. A számítógépes játék a racionalizáció esztétikai formája. [57]

Az elôadás címe (Videogames and the Spirit of Capitalism) alapján is nyilvánvaló, hogy Pedercini a „racionalizáció” fogalmával Max Weber A protestáns etika és a kapitalizmus szelleme címú múvére utal. ${ }^{[58]}$ Pedercini a „hatékonyság” és a „irányítás” uralmával szemben fogalmazza meg elôadása poétikus zárlatában saját játékkészítési alapelveit:

Egy új játékesztétikát kell találnunk, olyat, amely a problémamegoldás helyett a problémaalkotásban leli kedvét, amely a paradoxonokat és a megszakításokat ünnepli, amely nem ódzkodik az elrontott és diszfunkcionális rendszerektôl, mivel az életünket irányító elrontott és diszfunkcionális rendszereket feltárnunk kell, nem pedig eszményítenünk. Stratégiákat kell találnunk: a gépezetbe kell hajítanunk a költészet franciakulcsát, a fogaskerekeknek és a szelepeknek hajat kell növeszteniük, lüktetniük kell és lélegezniük, az algoritmusoknak meg kell tanulniuk történeteket mesélni és üvölteni a 
fájdalomtól. [59]

A Molleindustria különbözô játékai ezt az „új játékesztétikát” egészen eltérô poétikákkal képviselik. E játékok között akadnak színvonalasabb és kevésbé sikerült munkák, de poétikai szempontból a legegyszerúbbek is izgalmasak, mivel mindegyik egyedi kísérlet a bevett formák felszámolására.

\section{Level 1 - Procedurális játékretorikák}

Az előzô alfejezetben idéztem Pedercini álláspontját, miszerint a játékok közös jellemzôje, hogy hatékonyságot várnak el a játékostól, és azt, hogy a kezükben tartsák az irányítást. E megállapítások fényében érdekes a Molleindustria 2008-as játéka, a Kosmosis. ${ }^{[60]}$ A játék mellett olvasható meghatározás szerint a Kosmosis „arcade-játék egy alternatív szocialista univerzumból”, még pontosabban „communist space shooter”. A „space shooter” elnevezés meglepó, mivel a játékban - szemben a múfaj klasszikus darabjaival, mint amilyen a Space Invaders (Tomohiro Nishikado, 1978) - egyáltalán nem lehet lôni. A játék során az egér mozgatásával egy kis piros pontot kell irányítanunk a képernyôn, összegyújtve a kis kék pontokat (ürproletárok), kikerülve a kis zöld rombuszokat (ûrbeli kapitalista gócpontok). Ha már több úrproletárt gyújtöttünk magunk mellé, akkor a space billentyú megnyomásával sztrájkba kezdhetünk, és ilyenkor nekik ütközve lehetôségünk nyílik a kapitalista fellegvárak felszámolására. Az is előfordulhat ugyanakkor, hogy nem mi kezdeményezzük a sztrájkot a csoportunkban, ahogyan az is, hogy a mi csoportunktól leszakadó tömeg kezd sztrájkba. 


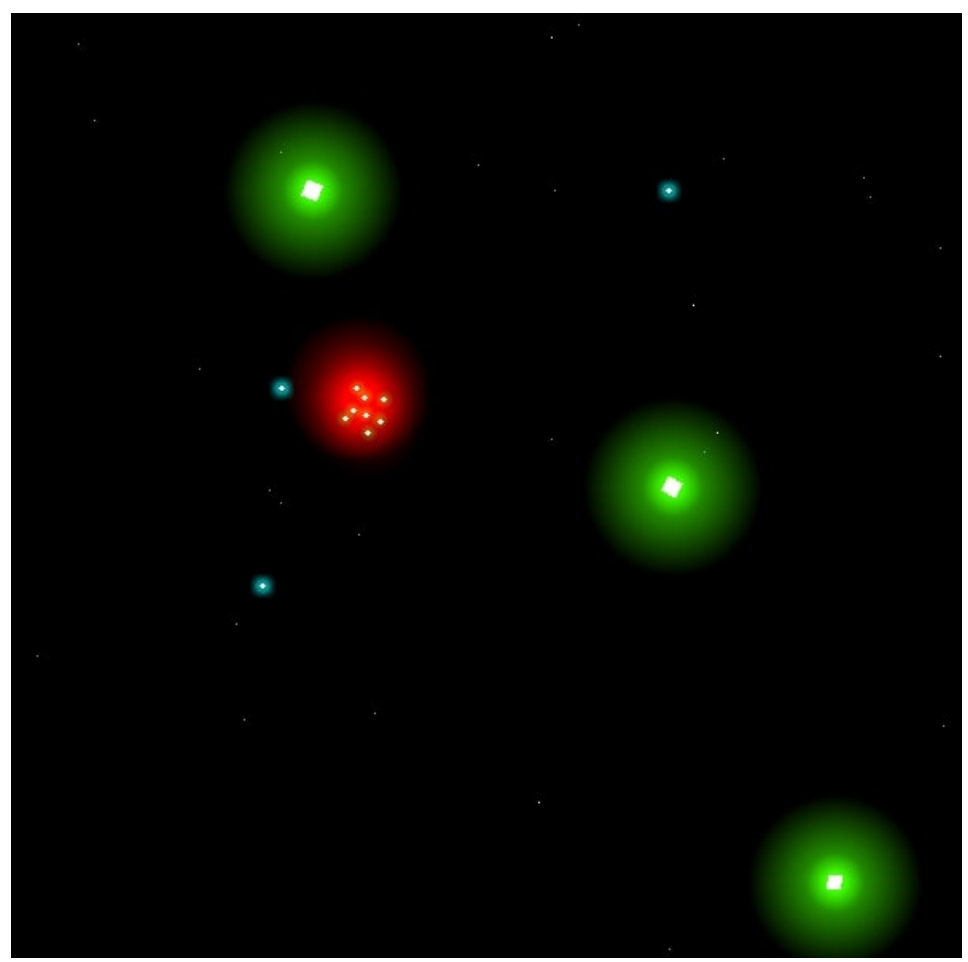

Kosmosis (Molleindustria, 2008)

Ahogy a csoportunk egyre nagyobbá válik, bármennyire is próbáljuk az egyik vagy a másik irányba terelni, egyre kevésbé tudjuk irányítani azt a tömeget, melynek mi magunk is a részei vagyunk. Különösen érdekes az a szituáció, ha a saját fénylô pontunk túl közel kerül az egyik zöld rombuszhoz, és megsemmisül: ekkor a játék az Internacionálé csengôhangszerú dallamával kísérve kiírja, hogy a mi utunk ugyan véget ért, de a harc folytatódik, mi pedig figyelemmel kísérhetjük a tömeg további küzdelmét. A játék változatlanul folyik - nélkülünk.

A Kosmosis esetében tehát a játékos fokozatosan elveszíti az irányítást a játék fölött, ${ }^{[61]}$ a játékbeli események pedig nélkülünk épp úgy alakulnak, ahogy velünk alakulnának. A játék kiiktatja magát a játékost. Ez a poétikai innováció egyrészt a kizökkentés eszköze, másrészt nyilvánvaló ideológiai üzenettel bír, mivel csökkenti az egyén jelentôségét a tömeg jelentôségével szemben. A Kosmosis arra szoktat, hogy váljunk a tömeg részévé, ahelyett, hogy az élére akarnánk állni.

A játék értelmezéséhez célszerú ismernünk azt a játéktípust, amelybe tartozik, és a hagyományt, amelybe illeszkedik. Az ûrben játszódó „shoot 'em up” típusú játékok egyik elsô darabja a Spacewar! (Steve Russel et al., 1962), mely egyben az egyik elsố számítógépes játék is. A játékot egy radarképernyő́n játszották, és az MIT kutatói fejlesztették ki, akiknek a kutatásait a hidegháborús idôkben szinte teljes egészében az Egyesült Államok Védelmi Minisztériuma finanszírozta. Pedercini szerint ez a történet önmagában is jól illusztrálja a hadiipar és a játékipar összefonódását (military-entertainment-complex). A hadviselést népszerúsítô játékokra számos példát hozhatunk, ahogy arra a helyzetre is, amikor az ilyen játékok nyilvánvalóan propagandisztikus célokat szolgálnak, gondoljunk csak az America's Army (United States Army, 2002) címú FPS-re, melyet az 
Amerikai Egyesület Államok hadserege adott ki, ${ }^{[62]}$ és melyet a katonai szolgálat népszerúsítésére és toborzásra használ. ${ }^{[63]}$ A Kosmosis teljesen elszakad ettôl a militáns hagyománytól: egyrészt nem lehet lôni benne, másrészt a képernyôn látható „szereplôk” absztrakt formák, melyek nem hasonlítanak a játéktípusban megszokott űrhajókra vagy vadászgépekre.

A Molleindustria játékai többségének esetében az adott játéktípus hagyománya kiemelten fontos szerepet kap. A 2003-as Tamatipico [64] címú játékuk például egy meglehetôsen unalmas és értelmetlen játéknak tûnik, ha nem ismerjük a tamagotchi múfaját. A tamagotchi a 90-es évek végének egyik legnépszerúbb játéka, egy kulcscsomóra illeszthetô szimulátor, melyben egy virtuális háziállatot kell gondoznunk. Elsősorban arra kell ügyelnünk, hogy kielégítsük állatunk igényeit (etetés, itatás, takarítás, szórakozás stb.), a játék bizonyos változataiban pedig fejleszthetjük is kedvencünk képességeit. Ezzel szemben a Tamatipico esetében egy virtuális munkás (flexworker) életét kell irányítanunk, aki mindössze három dolgot tud csinálni: dolgozni, aludni és pihenni (vagyis tévét nézni). A három tevékenység a walesi szocialista politikus, Robert Owen 1817-ben meghirdetett, majd a munkásmozgalomban hosszú ideig nagy népszerûségnek örvendô programját idézi, mely a munkanapot három nyolcórás részre osztotta (munka, szórakozás, pihenés), és a negyvenórás munkahét bevezetését javasolta. Ezt az intézkedést aztán - ironikus módon - pont a klasszikus kapitalizmus emblematikus intézménye, Henry Ford autógyára vezette be (és tette ezzel általánosan elfogadottá) 1926-ban, a gyár produktivitásának serkentésére és az autóvásárlási kedv növelésére. A Tamatipico kritikájának tárgya azon lehetôségek szúk köre, melyet a munkásoknak a posztfordista kapitalizmus felkínál. 


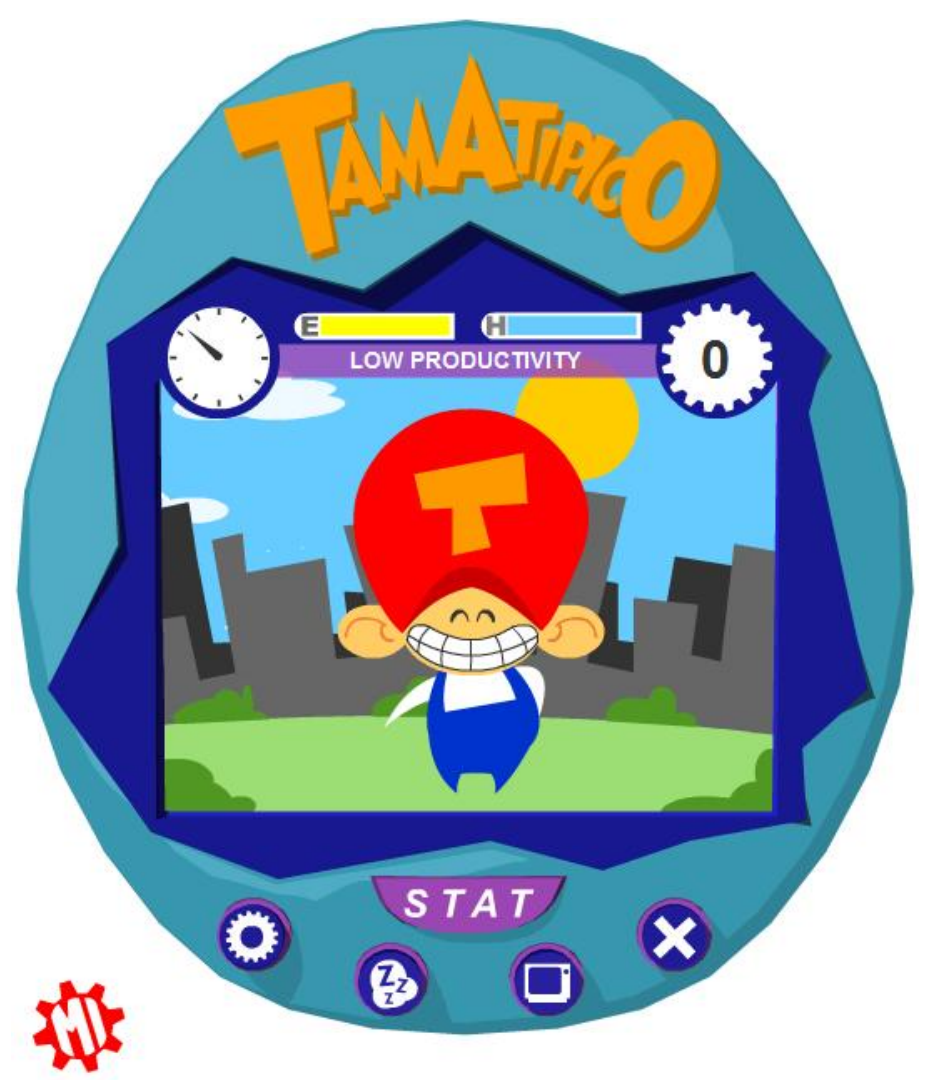

Tamatipico (Molleindustria, 2003)

A Tamatipico által felkínált lehetôségek a hagyományos tamagotchikhoz képest is meglehetôsen szúkre szabottak, a három folyamatot ismételve a játék gyorsan unalmassá válik. A tapasztalt unalommal a játék az átlagember (vagy az átlagos munkás) életének egyhangúságára akarja irányítani a figyelmünket. ${ }^{[65]}$ Még érdekesebbé válik a játék, ha ismerjük a tamagotchikhoz kapcsolódó ezredfordulós kulturális trendeket, például azt a gyakorlatot, hogy a gyászoló játékosok a virtuális háziállatokat valódi temetôkben helyezték örök nyugalomra. Innen nézve a játék arra mutat rá, hogy miközben sokan komoly empátiát éreznek párbites virtuális állatok iránt, addig a társadalomra jóval kevésbé jellemzó az empátia és a szolidaritás azok iránt, akiknek az életét a kapitalista gazdasági rendszer és annak kulturális logikája még a tamagotchi-állatok alulkódolt valóságánál is sivárabbá és automatizáltabbá teszi.

Noha az irodalmi szövegek és a filmek esetében egyáltalán nem szokatlan, hogy az adott mú reflektál a saját múfaji hagyományaira, a számítógépes játékok esetében ez kevésbé gyakori jelenség. Espen J. Aarseth 2004-ben azt írta, hogy „a játékok még csak nem is intertextuálisak; a játékokat önmagukban kell értelmeznünk”. ${ }^{[66]}$ Aarseth ezt azzal indokolja, hogy „nem kell ismernünk a pókert vagy a »Ki nevet a végén?«-t ahhoz, hogy megértsük a sakkot, a rulett ismerete pedig nem visz közelebb annak a megértéséhez, hogy mi is az az orosz rulett". [67] Utóbbiakban kétségtelenül igaza van, de pusztán azért, mert különböző játéktípusokról ír. A Molleindustria játékai esetében fontossá válik az adott játéktípus korábbi darabjaihoz való viszony, hiszen a játékok retorikája gyakran az ezekhez való viszonyra épül. Ebben az értelemben a Molleindustria 
játékai intertextuálisak és önreflexívek. Az Unnamed ${ }^{[68]}$ elsôsorban a katonai játékokkal való viszonya alapján értelmezhetô. Az általunk irányított drónpilóta otthon a kisfiával egymás után két háborús FPS-el is játszik, az elsôben terroristákat kell lelôni, a másodikban német katonákat, de a két játék egyébként szinte teljesen megegyezik. A játékbeli játékok gyorsasága és mozgalmassága, az FPS-ek által felkínált „hősiességérzet” és sikerélmény éles kontrasztba kerül az általunk irányított drónpilóta életével. Az A Phone Story ${ }^{[69]}$ csak mobiltelefonon (iOS és android operációs rendszereken) játszható, mivel a játék a mobiltelefonok alkotóelemeinek előállításához vezetô kizsákmányolás folyamatáról szól, ahol mi játszhatjuk a kizsákmányolókat. A The Best Amendment [ ${ }^{70]}$ címú fegyverviselés-ellenes játékuk a számítógépes játékot mint médiumot ért kritikákra reflektál. Minden játékmenet végén felugrik egy kép egy felirattal, az egyik alkalommal a játékosnak egy Rorschach-tesztet kell kitöltenie, amely azt vizsgálja, hogy mennyire vált agresszívvá a játéktól, egy másik esetben pedig a játék azt javasolja nekünk, hogy menjünk ki egy kicsit a szabadba levegôzni. A robotizáció nyomán kialakuló munkanélküliségrôl szóló To Build a Better Mousetrap, ${ }^{[71]}$ valamint a dzsentrifikiációt tematizáló Nova Alea ${ }^{[72]}$ a menedzsment-játékok és a várostervezô stratégiai játékok hagyományára épít.

A Molleindustria legsikeresebb játékai azok, melyek gigavállalatok múködésébe vezetik be a játékost. Első ilyen játékuk a 2006-os McDonalds - The Video Game, ${ }^{[73]}$ mely a céget reklámozó menedzsment-játéknak tünteti fel magát. A játékban ugyanakkor nem csak a hozzávalók beszerzését és az éttermeink pultjainál álló dolgozók számát állíthatjuk be, de megvesztegethetünk egészségügyi ellenôröket, létrehozhatunk minket támogató, függetlennek tetszô civil szervezeteket, gyanús vegyszerekkel növelhetjük teheneink méretét, egy pont után a fertôzések miatt elpusztult teheneinket megetethetjük a még élô teheneinkkel, és lerombolhatunk harmadik világbeli falvakat azért, hogy hasznos termóföldhöz jussunk. A játékot nem nehéz megnyerni, hiszen lényegében arról szól, hogy a jelenlegi korlátok mellett nem veszíthetünk. A McDonalds The Videogame célja, hogy procedurálisan ábrázolja a McDonalds és a hozzá hasonló óriásvállalatok stratégiáit. Hasonló módón múködik a Leaky World, ${ }^{[74]}$ amely Julian Assange Conspiracy as Governance ${ }^{[75]}$ címú esszéjében vázolt elméletének ,játszható” változata (alcíme szerint „a playable theory"), vagy a Free Culture Game, ${ }^{[76]}$ mely a kulturális javak piacon kívüli, szabad terjedését propagálja. Ezek a játékok tehát procedurális reprezentációk, melyek társadalmi rendszerek egyes vonásait emelik ki, rámutatnak bizonyos folyamatokra. [77]

Végül szót kell ejtenünk arról a stratégiáról, melyet Ian Bogost a „kudarc retorikájának” [rhetoric of failure] nevez. A kudarc retorikájára épülő, „megnyerhetetlen” játékok úgy hívják fel a figyelmet egy rendszer elhibázott voltára, hogy a játékosnak nem lesz lehetôsége megoldani a játék által felkínált feladatokat. ${ }^{[78]}$ Bogost legszemléletesebb példája Gonzalo Frasca September 12th: A Toy World (2003) ${ }^{[79]}$ címú játéka. A játékban egy arab kisváros lakóira lóhetünk ki rakétákat. A feladatunk az lenne, hogy a hétköznapi városlakók között ólálkodó terroristákkal végezzünk, csakhogy a város sürün lakott, a lövésünk pedig mindig késleltetve ér célt és nagy hatókörben robban, ezért nem tudjuk elkerülni, hogy civil áldozataink is legyenek. A halott civilek 
holttesteihez ilyenkor odasereglenek a városlakók, és a gyászolók közül páran mindig terroristának állnak. Akármennyire hatékonyan próbáljuk teljesíteni a feladatunkat, a beavatkozásaink hatására a terroristák száma mindenképpen nôni fog. Nem nyerhetjük meg a játékot, a kudarcunk pedig a játék procedurális argumentációjának része: „a terror elleni háború” az Egyesült Államok politikai közbeszédében gyakran előkerülő „war on terror” - nem megfékezi, hanem termeli a terrorizmust; vagyis nem a megoldást jelenti, hanem maga a probléma.

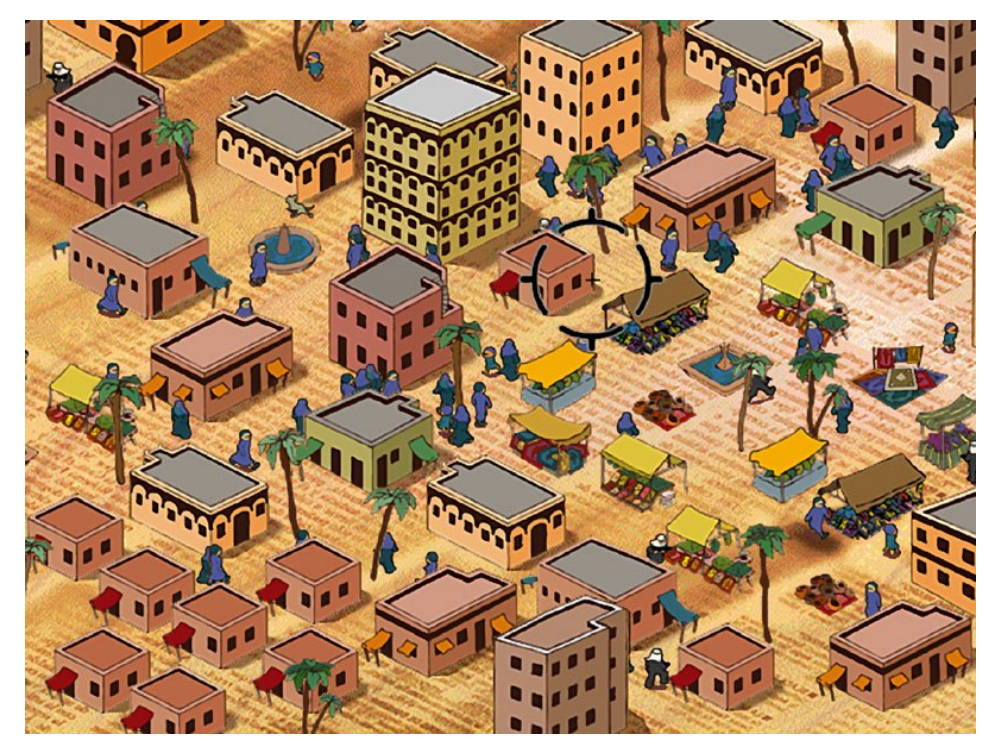

September 12th (Gonzalo Frasca, 2003)

Pedercini korábban említett játékai is ehhez hasonló eszközökkel élnek, noha nem épp úgy múködnek, mint a fenti példa. A Tamatipico nem „megnyerhetô”, de még a kudarc lehetôségét sem kínálja fel: nem nyerhetjük meg és nem veszíthetjük el, csak abbahagyni lehet. A Molleindustriának ugyanakkor olyan játéka is van, mely a jutalmazási rendszer megfordítására és a „kudarc retorikájára" épít. Ez a játék az Oiligarchy, mely komplexitása és számos innovatív megoldása miatt alaposabb elemzést érdemel, mint a fenti játékok.

\section{Level 2 - Az Oiligarchy}

Az Oiligarchy alapvetốn hasonló sémára épül, mint a McDonalds - The Videogame: a korábbi játék számos elemét tartalmazza, de ezek rendszerét tovább is fejleszti, valamint új lehetôségekkel gazdagítja. Lars Konzack Philosophical Game Designs címú tanulmányában pontosan meghatározta a McDonalds - The Videogame hiányosságait:

[...] a játék arra bátorítja a játékost, hogy ellenszenvet érezzen a McDonald's iránt, valamint a fejlett kapitalizmus hatékonysága és stratégiái iránt, amit a McDonald’s képvisel. Ebból a szempontból a játék hasznos propagandának tûnhet. Filozófiai játékként ugyanakkor 
nélkülözi az egyéb lehetôségek kipróbálásának és az alapelvek további vizsgálatának lehetôségét. Emellett a játék nem foglalkozik a problémákra adható megoldásokkal sem. Csak annyit állít, hogy amit a McDonald’s tesz, az többszintú korrupcióhoz és pusztításhoz vezet, de ha valaki hatékony és sikeres akar lenni, akkor ez az út, amit járnia kell. Ebben a tekintetben még az is kiderülhet, hogy mint anti-reklámjáték kontraproduktív, mert a játék azt mondja a játékosnak, hogy a való világban a korrupció az, ami múködik. [80]

Konzack tehát szkeptikus a játék kritikai erejét illetően, és felveti, hogy a hatékonyságra törekvő játékos pusztán stilárisan zárójelezett sikerélménye akár még meg is erôsítheti az elköteleződését a bírált minták iránt. A McDonalds - The Videogame-mel szemben az Oiligarchy több stratégiát kínál a játékosnak, ráadásul akadályokat görget a játékbeli siker lehetôsége elé.

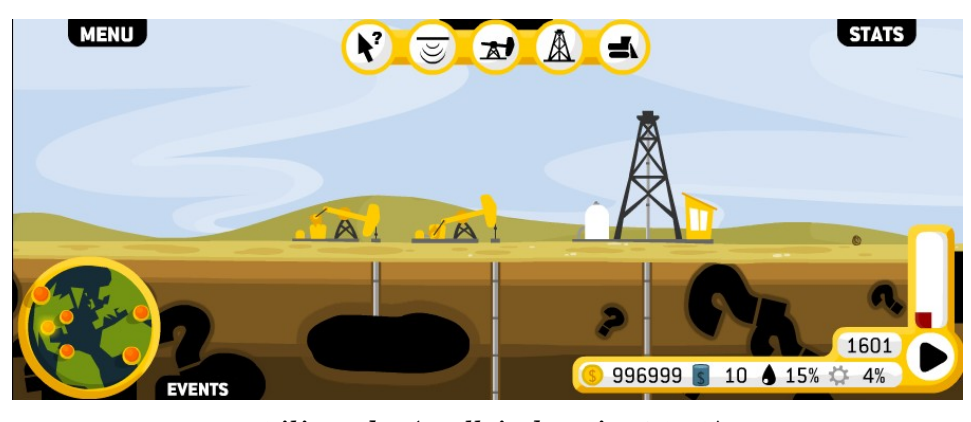

Oiligarchy (Molleindustria, 2008)

Noha pontos vonatkozó adataink nincsenek, szinte biztosra vehetjük, hogy az Oiligarchy ${ }^{[81]} \mathrm{a}$ Molleindustria eddigi legnépszerúbb játéka: e szöveg megszületésekor 10 millióan már biztosan játszottak vele, ${ }^{\left[{ }^{82]}\right.}$ rendszeresen bekerül a legjobb alkalmi játékokat listázó válogatásokba, és a netes fórumok tanúsága szerint komoly rajongótábort tudhat maga mögött. A stratégiai játékban egy olajvállalatot kell menedzselnünk. A feladatunk ugyanakkor nemcsak az, hogy új olajmezók után kutassunk, hogy kisebb és nagyobb szárazföldi és vízi fúrótornyokat építsünk a világ számos pontján, hogy megvesztegessük kisebb országok diktátorait, vagy hogy - a játék vége felé - az emberi testeket üzemanyaggá alakító üzemeket hozzunk létre. Négyévente lehetôségünk nyílik a választások befolyásolására is: ekkor az USA két nagy politikai pártját, a republikánusokat és a demokratákat jelképezô piros elefánt és kék szamár versenyt fut a képernyôn. Mindkét allegorikus robot-állat egy porszívófejben végzôdik, mi pedig azzal hathatunk a verseny eredményére, hogy ki elé szórunk több pénzt az addigi profitunkból. Minél több pénzt szánunk ilyen célokra, annál nagyobb hatást gyakorolhatunk az Egyesült Államok politikájára, a lefizetett képviselők az olajvállalatok számára kedvező döntéseket hoznak: leszavazzák a természetvédôk törvényjavaslatait, megkapjuk a szükséges engedélyeket az alaszkai kitermelés beindításához, csökkentik az adóterheinket stb. Ha mi birtokoljuk a többséget a szenátusban, akkor bejárást nyerhetünk a Fehér Ház alatti titkos terembe is, mely a White House Situation Room ironikus ábrázolásának tûnik. Innen gyakorlatilag mi robbanthatjuk ki az iraki háborút, mi hangolhatjuk a 


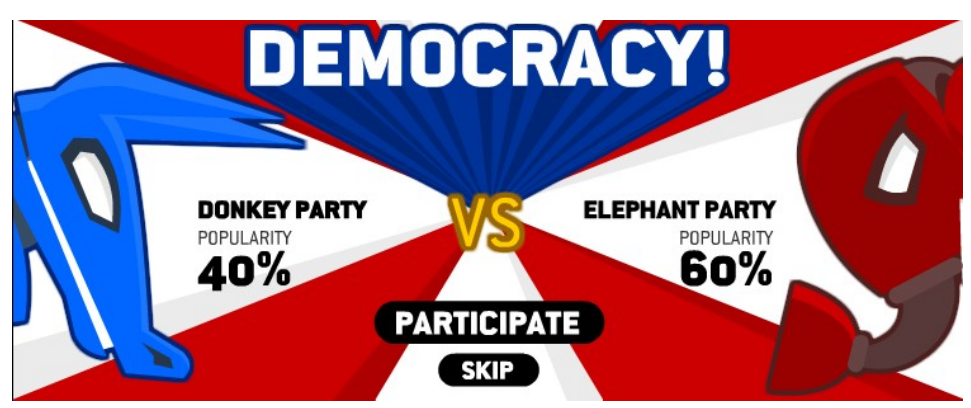

Oiligarchy (Molleindustria, 2008)

A játék üzenete világos: a képviseleti demokráciát a tôke irányítja, az Egyesült Államok politikáját a nagyvállalatok - fốképp az olajvállalatok - érdekei határozzák meg. A játék fiktív világa egyértelmúen szatirikus színezetú, magát a játékot pedig szatírának is tekinthetjük a fogalom Northrop Frye féle értelmében, aki szerint „a szatíra militáns irónia”. ${ }^{[83]}$ Az Oiligarchy mindent ironikusan eltúloz, részben azért, hogy még figyelemfelkeltôbb legyen, részben azért, mert ahogy azt Pedercini egyik elôadása után egy kérdésre adott válaszban megfogalmazta ${ }^{[84]}$ - a játék nem pusztán meggyôzni akarja a játékost, hanem a túlzás provokatív erejének segítségével arra akarja késztetni, hogy olvasson utána ezeknek a kérdéseknek, felderítve az eltúlzott ábrázolás mögötti valós arányokat. [85] 
Az Oiligarchy emellett határozott ökológiai álláspontot képvisel, de ezt másképp teszi, mint ahogy azt az ökojátékoktól megszokhattuk. ${ }^{\left[{ }^{[8]}\right.}$ A természet megjelenítése a játékban ironikus színezetú: beavatkozásainkkal sirályrajokat, színes trópusi madarakat és bálnákat üldözünk el azélôhelyükrôl, idilli őslakos falvakat semmisítünk meg, melynek lakói - érkezésünkig - naphosszatcsak a falu közelében rakott tábortűz mellett üldögéltek, nézegetve az egymással békésen játszó kölyökleopárdokat. A játék természeti képei rajzfilmszerūen idealizáltak, klisészerūek és elnagyoltak; ez az ábrázolás az ökológiai diskurzus közhelyeinek tárházává alakítja a játékbeli természetet. A természeti katasztrófákról a játéban fiktív újságcikkekből értesülünk, a szalagcímek alakulását a mi játékosi aktivitásunk határozza meg: az Oiligarchy az emberi beavatkozás hatásairól beszél, és nem magáról a természetrôl, annak fontosságáról vagy értékességéról. Az Oiligarchy a természetet károsító folyamatok bírálatára koncentrál, melyek a játék egyik lehetséges végkifejletében, a Föld lakhatatlanná válásában érnek a csúcsra. Pedercini játékában a természetet nem azért kell megvédenünk (vagy pusztán kisebb léptékben pusztítanunk), mert önmagában ,jó”, „csodálatraméltó” vagy „értékes”, hanem azért, mert a jelenlegi emberi beavatkozások kritikája az emberiség létérdeke. Az Oiligarchy tehát nem a természet jelentôsége mellett érvel, pusztán a tôke természetromboló gyakorlatával szembesít. Az irónia és a kizárólag az emberi beavatkozások hatására koncentráló fókusz akadályozza meg, hogy az Oiligarhcy csatlakozzon a kortárs „ökoideológia” idealizációs gyakorlatához, ahol az „anyatermészet” naiv, már-már spirituális színezetû kitüntetésével találkozunk. [87]

Ha a játék során hatékonyan irányítjuk a vállalatunkat, akkor hatalmas profitra tehetünk szert, viszont 2030 környékére elpusztul a földgolyó. A játék „etikusan” is játszható, ebben az esetben nem befolyásoljuk a pártpolitikát, és megpróbáljuk elkerülni azt is, hogy súlyos károkat okozzunk az ökoszisztémában. Ebben az esetben a vállalat részvényesei elégedetlenek lesznek a munkánkkal, ami ahhoz vezethet, hogy elbocsátanak minket. Ha egyensúlyozunk a két fenti magatartásforma a maximális piaci hatékonyság és a radikális ellenállás - között, vagyis ha nem a profit maximalizálására törekszünk, de nem is akarjuk csődbe vinni a vállalatunkat, akkor a cég élén maradhatunk, de közremúködhetünk abban, hogy az olaj világgazdasági szerepe fokozatosan csökkenjen. Így juthatunk el a játék harmadik befejezéséhez: a világ az alternatív energiaforrások felé fordul, és a Föld megmenekül. [88] 


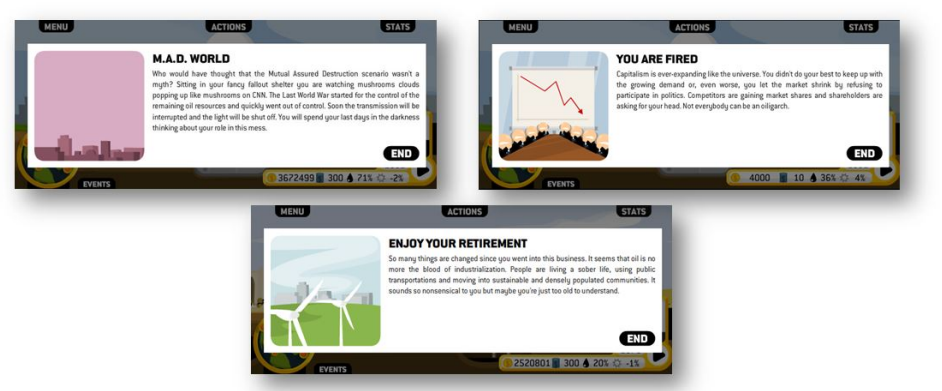

Az Oiligarchy (Molleindustria, 2008) lehetséges befejezései.

Az Oiligarchy esetében tehát - a legtöbb játékkal ellentétben - nem a maximális hatékonyság vezet a legjobb végkifejlethez. Maga Pedercini is ezt tekinti a játék legfontosabb sajátosságának: „úgy túnik, hogy a bináris gyôzelem/vereség formula relativizálása hat a legsokkolóbban a megrögzött játékosokra”. ${ }^{[89]}$ Az Oiligarchy esetében két játék-logika kombinálódik. Egyrészt magán viseli azon játéktípus sajátosságait, mely egy rendszer procedurális leképezésével mutat rá az adott rendszer hibáira, mint a McDonalds - The Video Game. Ugyanakkor nem éri be azzal, hogy a kritizált rendszert játszhatóvá teszi: a hatékony játékos nem jutalmazásban részesül, hanem negatív végkifejlettel szembesül, ami arra ösztönzi, hogy újabb stratégiákat válasszon. Annak ellenére, hogy a játékban könnyen lehetünk nagyon sikeresek és nagyon gazdagok, a játék rámutat, hogy a maximális hatékonyságra való törekvés maga a probléma. Vagyis az Oiligarchy a „kudarc retorikájának" stratégiájával él, miközben más játszható utakat is felkínál. Ezzel a játék rendszerkritikája magába építi a mi játékosi magatartásunkat is, mint a bírált rendszer múködési elveivel analóg stratégiát.

\section{Bossfight - Az elkötelezett játékok lehetôségei}

Dyer-Witheford és de Peuter megállapítja, hogy „a videojáték a Birodalom - az egész bolygót átfogó, militarizált hiperkapitalizmus - paradigmatikus médiuma”, de meghatározásukat kiegészítik azzal, hogy már felismerhetôk a törekvések, melyek ennek a játék-paradigmának a kihívóiként, ellenfeleiként lépnek fel. ${ }^{[90]}$ A videojátékok esetében egy fiatal médiummal van dolgunk, melynek területén épp most jelentek meg ezek a „kihívók”: az utóbbi két évtizedben kezdett kibontakozni az elkötelezett, kritikai videojátékok hagyománya. Egyes játékok a kooperáció sémáit próbálják a verseny mindent uraló logikájának helyébe állítani, más játékok politikai ügyekre akarják irányítani a játékosok figyelmét, vagy új perspektívát nyitnak a játékok területén gyakran reprezentált eseményekre és folyamatokra. [91]

A Molleindustria játékainak elemzése alapján arra következtethetünk, hogy egy kis, alkalmi játék fóképp akkor tehet szert számottevô ideológiakritikai hatóerôre, ha olyan radikális poétikai innovációval él, amely kizökkenti a játékost megszokott helyzetéből. Ez a kizökkentés a Molleindustria játékainak legfontosabb stratégiája. A játékos arra kényszerül, hogy feltegye a kérdést: „Miért 
veszítettem el a játék fölötti irányítást?” (Kosmosis), „Miért nem úgy viselkedik ez a játék, ahogy a játéktípustól megszoktam?” (Kosmosis, Tamatipico), „Miért nem tudom megnyerni ezt a játékot?” ( Tamatipico), „Miért bírál engem ez a játék, amikor jól játszottam?” (Oiligarchy). A Molleindustria játékai határozottan immerzióellenesek, a szimulációból való reflexív kimozdulásra sarkallják a

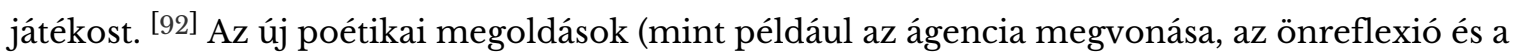
múfaji metareflexió, a „megnyerhetetlenség”, a „kudarc retorikája” és ezek sajátos kombinációi) kimozdítják a játékost a játékosi pozíciójából, aki így a korábbi médiumok által felkínált értelmezôi pozícióba kerül, és már nem játssza, hanem olvassa a játékot. Ezzel a játékos arra kényszerül, hogy a játék jeleinek és folyamatainak a játékvilágon túli referenciái felé forduljon. A Molleindustria esetében ezek a retorikai megoldások nyitnak teret annak, hogy a játékok megfogalmazhassák a társadalmi és piaci folyamatok, játékok és játéktípusok, valamint a játékosi attitúd(ök) kritikáját. Ezek összekapcsolása teszi Paolo Pedercini játékait egyedivé: a játékok a mi játékosi magatartásunkat használják a bírált folyamatok logikájának szemléltetésére.

Ezt a procedurális retorikát tágabb múvészettörténeti kontextusban olyan stratégiának is tekinthetnénk, mely a múvészetként, „magaskultúraként” történô legitimációt célozza: a modernitás paradigmájában a formai önreflexiót, az avantgárd hagyományán belül pedig a múalkotásként való meghatározhatóság fölszámolását rendszeresen a múvészet alapvetô jellemzőjének tekintik. Pedercini nyilatkozatai alapján ugyanakkor világossá válik, hogy az alkotó a magas- és a populáris kultúra elkülönítését egyáltalán nem tekinti releváns oppozíciónak. A Molleindustria játékainak önreflexivitása és kizökkentô hatása nem azt célozza, hogy maguk az alkotások feljebb lépdelhessenek valamiféle esztétikai ranglétrán, mivel az elsôdleges céljuk minden esetben politikai. Éppen ezért célszerúbb a kultúra szociológiai fogalma helyett a kultúra politikai fogalma felé fordulnunk. ${ }^{[93]}$ Ebból a szempontból a Molleindustria játékai a - kultúriparral szemben meghatározott - kritikai kultúra vagy tömegkultúra kategóriájába tartoznak: ${ }^{[94]} \mathrm{a}$ megszakítás stratégiájával a kultúripar sematizmusával fordulnak szembe. Innen szemlélve a bemutatott játékok által múködtetett „kizökkentés” elsôsorban a brechti elidegenitéssel (Verfremdung ) mutat rokonságot. ${ }^{[95]}$ Brecht esztétikai programjának politikai célja az volt, hogy a passzív szórakozás lehetôségétôl megfosztott, az elôadás megalkotottságával folytonosan szembesülô befogadók ne „belemerüljenek” a színre vitt darabokba, hanem olyan reflexív pozícióba kerüljenek, mely lehetôséget ad komplex társadalmi folyamatok megértésére. A Molleindustria hasonló stratégiát múködtet a videojátékok területén.

A csoport játékainak fenti méltatása nem jelenti azt, hogy e játékok ne lennének számos szempontból bírálhatók. A szúk ábrázolási keretekboól adódóan csaknem minden játékuk leegyszerúsít komplex helyzeteket. Gyakran nem okoz nagy interpretatív erőfeszítést, hogy az eredeti szándékokkal ellentétes politikai üzeneteket társítsunk hozzájuk. A bemutatott játékok - a bevezetốben említett táblajátékokkal ellentétben - egyedül játszhatóak; a Molleindustria mindeddig nagyon kevés közösségi játékot hozott létre. A politikai üzenet azonosítása kapcsán kulcsfontosságú a játékokat körülölelő diskurzus, vagyis az az út, melyen keresztül a játékos a játékhoz jut: kérdéses, hogy a játékok vajon mennyire képesek megszólítani azokat, akik nem 
értenek egyet a beléjük épített érveléssel, már mielôtt játszani kezdenének velük. Jelenleg azt is nehéz lenne megjósolni, hogy a reflexív irónia alt-right-os „kisajátítása” ${ }^{[96]}$ a jövôben milyen fokon hat majd vissza az irónia alakzatának baloldali alkalmazhatóságára.

Végül Mark Fisher populáris kultúráról szóló elmélete nyomán az is kérdéses, hogy vajon az elkötelezett játékok megelégedhetnek-e az ideológiakritika hagyományos gyakorlataival, vagy inkább arra lenne szükség, hogy megpróbáljanak túllendülni a fennálló bírálatán, és olyan társadalmi és gazdasági rendszereket kezdjenek el modellezni, melyeket a kései kapitalizmus kulturális logikája elgondolhatatlanná tett számunkra. ${ }^{[97]}$ A Jacobin magazin nagyon hasonló kérdésére Paolo Pedercini azt válaszolta, hogy maga is ilyesmivel próbálkozik, mivel „itt az ideje, hogy előálljunk egy jobb jövô dinamikus, játszható verzióival”. [98]

[A tanulmány a Politikatörténeti Intézet Társadalomtörténeti Múhelye (PTI TEM) 2017-es ösztöndíjának köszönhetôen jött létre.

\section{Jegyzetek}

1. Ennek alapos összefoglalását nyújtja Mark Hayse Ideology szócikke a ludológia egyik legfontosabb enciklopédiájában. Wolf, Mark J. P. - Perron, Bernard (szerk.): The Routledge Companion to Video Game Studies. Routledge, New York/London, 2014. 442-450.

2. Kinder, Marsha: Playing with power in movies, television, and video games: from Muppet Babies to Teenage Mutant Ninja Turtles. University of California Press, Berkeley, 1991.

3. Provenzo, Eugene F.: Video Kids: Making Sense of Nintendo. Harvard University Press, Cambridge, 1991.

4. URL: https://www.youtube.com/watch?v=X6p5AZp7r_Q\&list=PLn4ob_5_ttEaA_vc8F3fjzE62esf9yP61 (Letöltés ideje: 2018.12.01.) Anita Sarkeesian videosorozatához kötôdik a „gamergate-nek” keresztelt esemény, melyet mára az alt-right egyik elsổ megjelenésének tekintenek, és mely során a videojátékosok szubkultúrájának radikálisan antifeminista része komoly támadást intézett a kutatónô ellen. Minderrôl átfogó képet nyújt Angela Nagle Kill All Normies címú, az utóbbi évek internetes „kultúrharcát” elemző kötetében. Nagle, Angela: Kill All Normies. Zero Books, Winchester/Washington, 2017. 19-27.

5. Bogost, Ian: Persuasive Games - The Expressive Power of Videogames. The MIT Press, Cambridge/London, 2007. 1-64.

6. Uo. $2-3$.

7. Uo. $28-29$.

8. A dolgozat késôbbi részeiben - különösen a mainstream játékok vizsgálatakor - több ilyet is említek majd.

9. Sartre, Jean-Paul: Mi az irodalom? Gondolat, Budapest, 1969. 27-160.

10. Kivételt képez ez alól Nick Dyer-Witheford és Greig de Peuter Games of Empire - Global Capitalism and Video Games címú kötete, melyben az Antonio Negri és Michael Hardt elgondolásaira támaszkodó szerzôpáros a videojátékok termelésének vizsgálata, valamint a mainstream játékok kritikája után külön fejezetet szentel a progresszív antikapitalista játékok szisztematikus tárgyalásának. Dyer-Witheford, Nick - de Peuter, Greig: Games of Empire - Global Capitalism and Video Games. University of Minnesota Press, Minneapolis/London, 2009. 183-230.

11. Ezek olyan, a közönséget bevonó színielőadások, melyek a társadalmi/gazdasági logikákra próbálnak 
rámutatni. A kategória Magyarországon legismertebb példája a Szociopoly.

12. A pártpolitikai játékok a 2000-es évek elejének amerikai elnökválasztási kampányai során kerültek a figyelem középpontjába, azóta pedig sorra bukkantak fel az elnökjelölti kampányokat szimuláló játékok. Magyarországon pártpolitikai játékok létrehozásával és terjesztésével eddig a Magyar Kétfarkú Kutya Párt (URL: http://ketfarkukutya.com/?page_id=138 - Letöltés ideje: 2018.12.01.) és a Magyar Szocialista Párt (URL: http://m3.mszpbudapest.hu/ - Letöltés ideje: 2018.12.01.) próbálkozott. A pártpolitikai témájú játékok mellett - melyek többnyire kimerülnek a politikai ellenfél lehető legegyszerúbb kifigurázásában az ezredforduló óta egyre több olyan videojáték születik, melyek esetében nem pusztán arról van szó, hogy a játékok egy pártpolitikai retorika részévé/eszközévé válnak, hanem arról, hogy maguk a játékok kívánnak állást foglalni különböző társadalmi kérdésekben. Engem ebben a tanulmányban az utóbbi kategória foglalkoztat.

13. Erre a kategóriára jó példa a gamergate kirobbanásában komoly szerepet játszó Depression Quest (Zoë Quinn, 2013), melyet Angela Nagle is említ (Nagle, Angela: i.m. 21.), de ide sorolhatjuk az ún. hírjátékok ( newsgames) többségét is. (Vö.: Bogost, Ian - Ferrari, Simon - Schweizer, Bobby: Nerwsgames - Journalism at Play. The MIT Press, Cambridge/London, 2010.) Szintén remek példa a The Evolution of Trust (Nicky Case, 2017) címú ,játszható” esszé, mely a fogolydilemmából kiindulva szemlélteti a bizalmatlanság társadalmi terjedését. URL: http://ncase.me/trust/ (Letöltés ideje: 2018.12.01.)

14. Vö.: Aarseth, Espen J.: Ergodikus irodalom. Replika, 2000. 40. sz., 203-218.

15. Schrank, Brian: Avant-garde Videogames - Playing with Technoculture. MIT Press, Massachusetts, 2014.

16. Bogost, Ian: i.m. 29-32., 229.; Dyer-Witheford, Nick - de Peuter, Greig: i.m. 198-199.; Konzack, Lars: Philosophical Game Design. In: Perron, Bernard - Wolf, Mark J. P.: The Video Game Theory Reader 2. Routledge, New York/London, 2009. 33-44., 41-42.; Andersen, Christian Ulrik: Writerly Gaming: Political Gaming. In: Andersen, Christian Ulrik - Pold, Soren Bro (szerk.): Interface Criticism: Aesthetics Beyond Buttons. Aarhus University Press, Aarhus, 2011. 185-187.; Newman, James A.: Best Before: Videogames, Supersession and Obsolescence. Routledge, London/New York, 2012. 48-50.; Raley, Rita: Tactical Media. University of Minnesota Press, Minneapolis/London, 2009. 4-5.; stb.

17. Rancière, Jacques: A felszabadult nézó. Múcsarnok Kiadó, Budapest, 2011.

18. Uo. 13.

19. Uo. 14 .

20. Uo.

21. Uo.

22. Aarseth, Espen J.: Múfaji zavar: a narrativizmus és a szimuláció múvészete. In: Fenyvesi Kristóf - Kiss Miklós (szerk.).: Narratívák 7. - Elbeszélés, játék és szimuláció a digitális médiában. Kijárat Kiadó, Budapest, 2008. 159-174.,161.

23. Uo. 169.

24. Uo. 163.

25. Uo.

26. 2017-es fejlemény, hogy Super Mario többé nem vízvezeték-szerelő: a Nintendo ekkor frissítette a karakter japán nyelvú profilját, melyben most már az áll, hogy Mario meghatározott állással nem rendelkező sportember, aki mindent csinál, ami „cool”. Vö.: Ashcraft, Brian: Mario Is Officially No Longer a Plumber. Kotaku, 2017. URL: https://kotaku.com/mario-is-officially-no-longer-a-plumber-1799118840 (Letöltés ideje: 2018.12.01.)

27. Kiss Gábor Zoltán: A részvétel módjai és a rövidformák - Folytatásos regények, epizódok és tévésorozatok. In: Thomka Beáta (szerk.): Befejezetlen könyv. Kijárat Kiadó, Budapest, 2012. 251-263., 252. 
(Kiemelés tólem.)

28. Vö.: Frasca, Gonzalo: Videogames of the Opressed: Videogames as a Means for Critical Thinking and Debate. Ludology.org, 2001. URL: http://www.ludology.org/articles/thesis/FrascaThesisVideogames.pdf (Letöltés ideje: 2018.12.01.), 25-27.; Bogost, Ian: Unit Operations - An Approach to Videogame Criticism. The MIT Press, Cambridge/London, 2006. 99-101.; Kiss Gábor Zoltán: Efemer galériák - Videojátékok kritikai megközelitésben. Gondolat, Budapest/Pécs, 2013. 102-105., 146.

29. Frasca, Gonzalo: Szimuláció vs. narratíva - Bevezetés a ludológiába. In: Fenyvesi Kristóf - Kiss Miklós (szerk.): Narratívák 7. - Elbeszélés, játék és szimuláció a digitális médiában. Kijárat Kiadó, Budapest, 2008. 125-142., 128.

30. Uo.

31. Uo.

32. Éppen ezért Espen J. Aarseth már kiiktatja saját szimuláció-definíciójából a „forrásrendszert”, és a szimulációt nem a reprezentációval, hanem a fikcióval szemben határozza meg. Szerinte a fikció „csak jelekből áll”, míg a szimuláció ,jelekból és egy dinamikus modellből, ami alakítja annak a viselkedését, és reagál arra, amit mi beleteszünk”. Aarseth, Espen J.: Doors and Perception: Fiction vs Simulation in Games. 2006., 1. URL: http://www.escritasmutantes.com/fileManager/file/fiction_Aarseth_jan2006.pdf (Letöltés ideje: 2018.12.01.)

33. Frasca, Gonzalo: Videogames of the Opressed, i.m. 26. (Saját ford.)

34. Murray, Janet H.: Hamlet on the Holodeck: The Future of Narrative in Cyberspace. The Free Press, New York, 1997. 143-144. (Saját ford.)

35. Eskelinen, Markku: The Gaming Situation. Game Studies, 2001. július, 1/1. sz. URL: http://www.gamestudies.org/0101eskelinen/ (Letöltés ideje: 2018.12.01.) (Saját ford.)

36. Nem minden ludológus annyira kritikus Murray álláspontjával szemben, mint Eskelinen. Ian Bogost például Murray és Eskelinen értelmezését egyaránt szélsőségesnek tekinti, és arra hívja fel a figyelmet, hogy a Tetris általa ismert változatában helyet kapott egy úgynevezett „boss key” („fönök gomb”), mely szünetelteti a játékot, ha az irodában tetrisezó játékos fơnöke éppen az ô asztala elôtt sétálna el. Ez Bogost szerint egyszerre gyengítheti és erôsítheti Murray értelmezését, amennyiben a játék az irodai munka elóli menekülésként tünteti fel magát, ugyanakkor ezzel a gombbal valóban ahhoz a közeghez kapcsolja a játékot, melyhez Murray kötötte. Bogost, Ian: Unit Operations, i.m. 101. (A játék magyar változataiban a „boss key” helyett egy „pause” gomb szerepel, melynek megnyomása után a képernyő jobb oldali részében egy gôzölgô kávéscsésze ikonját látjuk felvillanni, vagyis kávészünetet tartunk - ez Murray értelmezését látszik erôsíteni.)

37. Utóbbi csaknem minden ludológus munkásságában megfigyelhetô, és különösen abban az idôszakban volt hangsúlyos, amikor a ludológia saját legitimációját kívánta megerôsíteni azokkal szemben, akik más tudományterületekrôl fogtak bele a játékok tanulmányozásába. Jól illusztrálja a korábbi interpretációs módokkal szembeni szkepszist és a játékosi magatartás kulcsfontosságúvá válását Jesper Juul sokat idézett mondata: „Ha túlságosan a meglévő elméletekre támaszkodunk, az elfeledteti velünk azt, ami a játékokat játékokká teszi, mint például a szabályok, a célok, a játékosi aktivitás, a játékosi tevékenység játékvilágba vetülése, és a mód, ahogy a játék a játékos lehetséges cselekedeteit meghatározza.” Juul, Jesper: Games Telling stories? - A brief note on games and narratives. Game Studies, 2001. július, 1/1. sz. URL: http://www.gamestudies.org/0101/juul-gts/ (Letöltés ideje: 2018.12.01.) (Saját ford.)

38. Lásd Anita Sarkeesian az elsô fejezetben bemutatott munkásságát.

39. Pobłocki, Kacper: Becoming-state - The Bio-cultural Imperialism of Sid Meier's Civilization. Focaal European Journal of Anthropology, 2002. 39. sz., 163-177. A Civilization körüli vitákhoz lásd még: Kisantal 
Tamás: Játsszunk történelmet! - A számítógépes játékok történelemkoncepciói. Sic Itur ad Astra, 2013. 63. sz., 193-212.

40. Frasca, Gonzalo: The Sims: Grandmothers are cooler than trolls. Game Studies, 2001. július, 1/1. sz. URL: http://www.gamestudies.org/0101/frasca/ (Letöltés ideje: 2018.12.01.), és Sicart, Miguel: Family Values: Ideology, Computer Games \& The Sims. DIGRA Digital Library. URL: http://www.digra.org/wpcontent/uploads/digital-library/05150.09529.pdf (Letöltés ideje: 2018.12.01.).

41. Pedercini, Paolo: What To Do With Prison Architect, A Video Game About Building Prisons? Kotaku, 2014. URL: http://kotaku.com/what-to-do-with-prison-architect-a-video-game-about-b-1505204131 (Letöltés ideje: 2018.12.01.)

42. Sốt a legsikeresebb játékosi stratégia az, ha a „szegények” csoportja többet adózik, mint a gazdagabb rétegek. A SimCity adórendszerének kritikájához lásd: Bogost, Ian: Unit Operations, i.m. 103-107. A lehető legsikeresebb város felépítéséhez szükséges adókulcsokat az alábbi táblázat tartalmazza: Ramsey, Jamie: Ideal SimCity Tax Rates. SimCity Planning Guide. URL: http://www.simcityplanningguide.com/2013/11/ideal-tax-rates.html (Letöltés ideje: 2018.12.01.)

43. Barthes, Roland: Mitológiák. Európa Könyvkiadó, Budapest, 1983.

44. Barthes a Mitológiák esszéinek születési okát az alábbiakban foglalja össze: „Az elemzés kiindulópontja legtöbbször az a türelmetlenség volt, amely mindig elfog, valahányszor a sajtó, a múvészet vagy a közgondolkodás »természetes «-nek tüntet fel egy olyan valóságot, amely, jól lehet benne élünk, minden ízében történeti képződmény: egyszóval valósággal szenvedtem tôle, hogy a hétköznapi beszédmód lépten-nyomon összekeveri egymással a Természetet meg a Történelmet, és a magától értetôdô látványos meglobogtatásában akartam nyakon csípni az ideológiai szemfényvesztést, amely mögötte lappang." (Uo., 5.) Ezt az „összekeverést” a szakirodalom naturalizációként emlegeti. (Marcelli, Miroslav: A Barthes-példa. Kalligram, Pozsony, 2011. 200-202. és Allen, Graham: Roland Barthes. Routledge, London/New York, 2003. 96.) A Mitológiák esszéinek stratégiája, hogy leleplezik ezt a naturalizációs folyamatot (denaturalizál nak), és bemutatják az önmagukat természetinek feltüntetô konstrukciókról, hogy azok konstrukciók.

45. Orbanes, Philip: Monopoly: The World's Most Famous Game - And How it Got that Way. Da Capo Press, Cambridge, 2006.

46. Abban, hogy a Monopoly esetében a játékosok többsége nem foglalkozik a politikai üzenettel, nyilvánvalóan az is komoly szerepet játszik, hogy a legtöbb játékos gyermekkorában ismerkedik meg vele. Emellett az is tény, hogy számos kulturális produktum használja a Monopoly-t a kapitalizmus allegóriájaként.

47. A játék magyarországi fogadtatásához lásd: Haider Edit: A libajátéktól a Monopolyig - A lépegetô társasjátékok történetéról. Sic Itur ad Astra, 2013. 63. sz., 25-34.

48. Pedercini, Paolo: Molleindustria Manifesto. Molleindustria.org, URL: http://www.molleindustria.org/blog/molleindustria-manifesto-2003/ (Letöltés ideje: 2018.12.01.)

49. Önmeghatározásuk a Molleindustria honlapján olvasható. URL: http://www.molleindustria.org/blog/about/ (Letöltés ideje: 2018.12.01.)

50. Pedercini egyetemi kurzusainak listája online elérhetô. URL: http://mycours.es/ (Letöltés ideje: 2018.12.01.)

51. Pedercini saját játékairól - többek között - a Yes Lab 2014-es rendezvényén tartott elôadásában beszél (URL: https://www.youtube.com/watch?v=HQwTRKXZUxQ - Letöltés ideje: 2018.12.01.), a játékok és az ideológiai viszonyáról alkotott álláspontját pedig az Indiecade East 2014-es konferenciájára küldött, Videogames and the Spirit of Capitalism címú előadásában fejti ki (URL: http://www.molleindustria.org/blog/videogames-and-the-spirit-of-capitalism/ - Letöltés ideje: 
2018.12.01.).

52. Pedercini, Paolo: Molleindustria Manifesto, i.m. (Saját ford.)

53. Noonan, Luke: An artist interview with Paolo Pedercini / Molleindustria. ELP, 2010. 1. sz. URL: http://epc.buffalo.edu/ezines/elp/issue-1/pedercini.php (Letöltés ideje: 2018.12.01.)

54. Uo.

55. Friedman pontosan azt írja: „Szergej Eisenstein abban bízott, hogy a montázstechnika lehetôvé teszi majd Marx $A$ tókéjének megfilmesítését. Ezzel szemben a hollywoodi film narratív technikái olyan irányt vettek, melyek a nézôt inkább az egyénekre, semmint az absztrakt koncepciókra tették érzékennyé. $A$ tôkén alapuló számítógépes játékot ugyanakkor könnyú elképzelni.” Friedman, Ted: The Semiotics of Sim City. First Monday, 4. évf. 4. sz., 1999. április. URL: http://firstmonday.org/ojs/index.php/fm/article/view/660/575 (Letöltés ideje: 2018.12.01.) (Saját ford.) David Cribb 2016-os játéka, a Crisis Theory A tôke egyes megállapításainak procedurális ábrázolására tesz kísérletet. URL: https://colestia.itch.io/crisis-theory (Letöltés ideje: 2018.12.01.)

56. Vö.: Bogost, Ian: Persuasive Games, i.m. 29-32., 229.

57. Pedercini, Paolo: Videogames and the Spirit of Capitalism, i.m. (Saját ford.)

58. Weber, Max: A protestáns etika és a kapitalizmus szelleme. Gondolat, Budapest, 1982.

59. Pedercini, Paolo: Videogames and the Spirit of Capitalism, i.m. (Saját ford.)

60. Kosmosis (Molleindustria, 2008). URL: http://www.molleindustria.org/kosmosis/kosmosis.html (Letöltés ideje: 2018.12.01.)

61. A játékos ágenciájának felfüggesztéséből adódó egyéb kreatív lehetôségekhez lásd: Kiss Gábor Zoltán: Efemer galériák, i.m. 144-145.

62. A játék kapcsán tanulságos Lars Konzack egyik megjegyzése: „Szintén érdekes az America’s Army kapcsán, hogy ha a játékosok egymás ellen játszanak, akkor minden játékos az amerikai hadsereg tagjának látja a saját karakterét, ellenfelét pedig terroristának. Tehát amikor a játékosok egymással játszanak, mindegyik terroristákat irányít a többi játékos szemszögéból, és mindegyik amerikai katonát a saját szemszögéböl.” Konzack, Lars: Philosophical Game Design, i.m., 42.

63. Dyer-Witheford, Nick - de Peuter, Greig: Games of Empire, i.m. xii., 183-230.

64. Tamatipico (Molleindustria, 2003). URL: http://www.molleindustria.org/en/tamatipico/ (Letöltés ideje: 2018.12.01.)

65. Hasonló a helyzet a TuboFlex (Molleindustria, 2010) esetében is (URL: http://www.molleindustria.org/en/tuboflex/ - Letöltés ideje: 2018.12.01.), ami egyszerre illeszkedik a tamagotchik és az olyan játékok hagyományába, ahol a játékosnak minél gyorsabban és minél pontosabban kell az egérrel klikkelnie ahhoz, hogy tovább juthasson a játékmenetben (point and click games ). E játék struktúrája ugyanakkor nem a fejlődésre, a folyamatos szintlépésre és az egyre nehezedô feladatokra épül: a pályák struktúrája körkörös, a feladatok folyamatosan ismétlódnek, a játék megnyerhetetlen, és ezzel épp annyira mechanikussá és unalmassá válik, mint a bemutatott munkakörök. A TuboFlex központi témája Rita Raley értelmezésében a posztindusztriális munkalehetôségek alapvetően bizonytalan jellege. Raley, Rita: Tactical Media, i.m. 4.

66. Aarseth, Espen J.: Múfaji zavar: a narrativizmus és a szimuláció múvészete, i.m. 162.

67. Uo.

68. Unnamed (Molleindustria, 2012). URL: http://unmanned.molleindustria.org/ (Letöltés ideje: 2018.12.01.)

69. A Phone Story (Molleindustria, 2011). URL: http://www.phonestory.org/ (Letöltés ideje: 2018.12.01.)

70. The Best Amendment (Molleindustria, 2013). URL: http://www.molleindustria.org/the-best-amendment/ 
(Letöltés ideje: 2018.12.01.)

71. To Build a Better Mousetrap (Molleindustria, 2014). URL: http://www.molleindustria.org/to-build-a-bettermousetrap/ (Letöltés ideje: 2018.12.01.)

72. Nova Alea (Molleindustria, 2016). URL: http://molleindustria.org/nova-alea/ (Letöltés ideje: 2018.12.01.)

73. McDonalds - The Video Game (Molleindustria, 2006). URL: http://www.mcvideogame.com/ (Letöltés ideje: 2018.12.01.)

74. Leaky World (Molleindustria, 2010). URL: http://www.molleindustria.org/leakyworld/leakyworld.html (Letöltés ideje: 2018.12.01.)

75. Julian Assange esszéje a játék alatt olvasható.

76. Free Culture Game (Molleindustria, 2008). URL: http://www.molleindustria.org/en/freeculturegame/ (Letöltés ideje: 2018.12.01.)

77. A politikai játékoknak föképp ezt az aspektusát hangsúlyozza Ian Bogost, mikor azt írja: „A politikai játékok procedurális retorikája politikai folyamatok összefüggéseirôl tesznek állításokat, arról, hogy miért múködnek, miért nem múködnek, és miért válhatna a társadalom hasznára a megváltozatásuk." Bogost, Ian: Persuasive Games, i.m., 98. (Saját ford.) Jó példa a játéktípusra a The ReDistricting Game (USC Game Innovation Lab, 2006, 2015 - URL: http://www.redistrictinggame.org/game.php, Letöltés ideje: 2018.12.01.), mely nagyon hatékonyan szemlélteti, mekkora mértékben torzíthatja a választási eredményeket a szavazókörzetek határainak átrendezése.

78. Bogost, Ian: Persuasive Games, i.m. 84-89. A játékbeli „kudarc” funkcióinak kérdéséhez lásd: Juul, Jesper: Fear of Failing? - The Many Meanings of Difficulty in Videogames. In: Perron, Bernard - Wolf, Mark J. P.: i.m. 237-252.

79. September 12th (Gonzalo Frasca, 2003). URL: http://www.newsgaming.com/games/indexl2.htm (Letöltés ideje: 2018.12.01.) A játék a ludus és paidia fogalompárja felóli értelmezéséhez lásd: Gerencsér Péter: myContent.swf - A Flash-esztétika diskurzusai. Médiakutató, 2016. XVI. évf. 2. szám, 29-40., 35.

80. Konzack, Lars: Philosophical Game Design, i.m. 42. (Saját ford.)

81. Oiligarchy (Molleindustria, 2008). URL: http://www.molleindustria.org/en/oiligarchy/ (Letöltés ideje: 2018.12.01.)

82. Az Addicting Games lapján majdnem 7 milliószor, az Armor Games lapján pedig 1.3 milliószor indították el a játékot, de emellett még több száz honlapról elérhető, köztük a Molleindustria saját lapjáról.

83. Frye, Northrop: A kritika anatómiája. Helikon, Budapest, 1998. 189.

84. Az elôadás (Pedercini, Paolo: Making Games in a Fucked Up World, G4C14) az alábbi linken tekinthető meg: https://www.youtube.com/watch?v=MflkwKt7tl4 (Letöltés ideje: 2018.12.01.)

85. A Molleindustria minden játéka mellól elérhetőek az adott játék által tematizált problémáról szóló publicisztikai írások és szakirodalmak.

86. Az ökojátékokról és a játékbeli virtuális élő környezetekrôl alapos összefoglalót nyújt Alenda Y. Chang doktori disszertációja. Chang, Alenda Y.: Playing Nature - The Virtual Ecology of Game Environments. University of California, Berkeley, 2013. URL: http://escholarship.org/uc/item/9ch2w332\#page-1 (Letöltés ideje: 2018.12.01.)

87. Ebből a szempontból a játék szemlélete olyan kritikai ökológusok, biológusok és filozófusok elképzeléseivel rokonítható, mint Timothy Morton, Steven Vogel vagy Slavoj Žižek. Vö.: Morton, Timothy: Ecology Without Nature - Rethinking Environmental Aesthetics. Harvard University Press, Cambridge/London, 2009.; Morton, Timothy: Ecology after Capitalism. Polygraph, 2010. 22. sz., 46-59.; Vogel, Steven: Environmental Philosophy after the End of Nature. Environmental Ethics, 2002. 24/1., 
23-39.; Žižek, Slavoj: Censorship Today: Violence, or Ecology as a New Opium for the Masses. Lacan.com, URL: http://www.lacan.com/zizecologyl.htm (Letöltés ideje: 2018.12.01.) Ehhez a kérdéshez lásd még: Canavan, Gerry - Klarr, Lisa - Vu, Ryan: Ecology \& Ideology - An Introduction. Polygraph, 22. sz., 2010. 1-31., és Kapelner Zsolt: Ôrzői vagyunk-e a természetnek? a szem, 2017. URL:

http://aszem.info/2017/07/orzoi-vagyunk-e-a-termeszetnek/ (Letöltés ideje: 2018.12.01.)

88. Pedercini a játékról írt esszéje alapján az Oiligarchy-nak van egy negyedik végkimenetele is, ugyanakkor ez a játék mechanikája alapján gyakorlatilag elérhetetlen. Pedercini, Paolo: Oiligarchy Postmortem. URL: http://www.molleindustria.org/oiligarchy-postmortem/ (Letöltés ideje: 2018.12.01.)

89. Uo.

90. Dyer-Witheford, Nick - de Peuter, Greig: Games of Empire, i.m. xv.

91. Utóbbira a legjobb példa a This War of Mine (11 bit studios, 2014) címú pacifista játék, mely a háborút alulnézeti perspektívából, a túlélésért küzdő civilek szemszögéból ábrázolja.

92. Ha ezt a jelenséget Bagi Zsolt Az esztétikai hatalom elmélete címú kötetében megfogalmazott kultúraelmélete felól szemléljük, akkor az eddig bemutatott sajátosságok még komolyabb jelentôséget nyernek (Bagi Zsolt: Az esztétikai hatalom elmélete - Kulturális felszabadítás egy újbarokk korban. Napvilág Kiadó, Budapest, 2017.). Bagi jelenünket „újbarokk” kornak tekinti, melyet elsôsorban a reflexivitást alapjaiban ellehetetlenítő immerzivitás jellemez. (Uo. 29., 41-42.) A kötet elsô tanulmányának politikai/esztétikai programja a barokk és a klasszicizmus szembeállítására épül, és azt sugallja, hogy utóbbiban találjuk az újbarokk meghaladásának lehetôségét, mivel „a klasszicizmus immerzióellenes”, vagyis „fenntartja az esztétikai távolságot, ahelyett hogy elmerülne a szimulációban”. (Uo. 42.) Minden bizonnyal bonyolult feladat volna a Molleindustria játékait beilleszteni a múalkotások Bagi által felvázolt kategóriarendszerébe, azt viszont megállapíthatjuk, hogy poétikájuk legfontosabb sajátossága pontosan az, amit Bagi a barokkal szembeállított klasszicizmus legfontosabb jellegzetességének tekint.

93. Vö.: „A kultúra emancipációs fogalma politikai, nem pedig szociológiai. Kevésbé érdekel minket az elit- és a populáris kultúra ellentéte, mint az a kérdés, miként lehet bárki számára szóló kultúrát létrehozni." (Uo. 86).

94. Bagi a kritikai kultúra fogalmát a „magas” és az „alacsony” kultúra közötti különbségtétel meghaladására vezeti be: „Kérdés azonban, hogy valaha támaszkodott-e a modernitás emancipációs diskurzusa ezekre a fogalmakra egyáltalán, nem csupán arról van-e szó, hogy a »magas«- és az »alacsony«-kultúra fogalma éppenséggel egy emancipációellenes vagy ideologikus nyelv kifejezései arra, amit sokkal adekvátabban nevezhetünk kritikai kultúrának, illetve kultúriparnak." (Uo. 93.) A tömegkultúra fenti értelemében nem a populáris, a népi, vagy a „nagyon sokak számára szóló” kultúrát jelöli, hanem a „bárki számára adott” kultúrát. (Uo. 133-134.)

95. A fogalom általam alapul vett megközelítéséhez lásd: Stam, Robert: Reflexivity in Film and Literature - From Don Quixote to Jean-Luc Godard. Columbia University Press, New York, 1992. 212.

96. Angela Nagle álláspontja szerint a határsértés (transgression) és az irónia hosszú évtizedeken keresztül a radikális baloldal bevett politikai stratégiái voltak, az utóbbi évek „kultúrharcaiban” ugyanakkor megfigyelhetjük, hogy az internetes szubkultúrából apránként meghatározó jelentôségú jobboldali politikai mozgalommá váló „alt-right” fokozatosan kisajátította ezeket a stratégiákat. Az irónia - egyéb szubverzív stratégiákhoz hasonlóan - olyan sémává alakult, melyet használói nem meghatározott társadalmi célok szerint, hanem pusztán önmagáért (vagy ahogyan Nagle szellemesen megfogalmazza: ,just for the lulz”) alkalmaznak. Vö.: Nagle, Angela: i.m. 1-9., 21-39.

97. Fisher, Mark: Capitalist Realism. Zero Books, London, 2009. 1-11.

98. Partin, Will: Socialism at Play - An interview with Paolo Pedercini. Jacobin Magazine, 2017.08.09. URL: https://www.jacobinmag.com/2017/08/paolo-pedercini-interview-gaming-industry-molleindustria 


\section{Irodalomjegyzék}

- Aarseth, Espen J.: Doors and Perception: Fiction vs Simulation in Games, 2006., 1. URL: http://www.escritasmutantes.com/fileManager/file/fiction_Aarseth_jan2006.pdf (Letöltés ideje: 2018.12.01.)

- Aarseth, Espen J.: Ergodikus irodalom. Replika, 2000. 40. sz., 203-218.

- Aarseth, Espen J.: Múfaji zavar: a narrativizmus és a szimuláció múvészete. In: Fenyvesi Kristóf - Kiss Miklós (szerk.): Narrativák 7. - Elbeszélés, játék és szimuláció a digitális médiában. Kijárat Kiadó, Budapest, 2008. 159-174.

- Allen, Graham: Roland Barthes. Routledge, London/New York, 2003. https://doi.org/10.4324/9780203634424

- Andersen, Christian Ulrik: Writerly Gaming: Political Gaming. In: Andersen, Christian Ulrik Pold, Soren Bro (szerk.): Interface Criticism: Aesthetics Beyond Buttons. Aarhus University Press, Aarhus, 2011. 185-187.

- Bagi Zsolt: Az esztétikai hatalom elmélete - Kulturális felszabadítás egy újbarokk korban. Napvilág Kiadó, Budapest, 2017.

- Barthes, Roland: Mitológiák. Európa Könyvkiadó, Budapest, 1983.

- Bogost, Ian - Ferrari, Simon - Schweizer, Bobby: Nerwsgames - Journalism at Play. The MIT Press, Cambridge/London, 2010. https://doi.org/10.7551/mitpress/8854.001.0001

- Bogost, Ian: Persuasive Games - The Expressive Power of Videogames. The MIT Press, Cambridge/London, 2007.

- Bogost, Ian: Unit Operations - An Approach to Videogame Criticism. The MIT Press, Cambridge/London, 2006.

- Canavan, Gerry - Klarr, Lisa - Vu, Ryan: Ecology \& Ideology - An Introduction. Polygraph, 22. sZ., 2010. 1-31.

- Chang, Alenda Y.: Playing Nature - The Virtual Ecology of Game Environments. University of California, Berkeley, 2013. URL: http://escholarship.org/uc/item/9ch2w332\#page-1 (Letöltés ideje: 2018.12.01.)

- Dyer-Witheford, Nick - de Peuter, Greig: Games of Empire - Global Capitalism and Video Games. University of Minnesota Press, Minneapolis/London, 2009.

- Eskelinen, Markku: The Gaming Situation. Game Studies, 2001. július, 1/1. sz. URL: http://www.gamestudies.org/010leskelinen/ (Letöltés ideje: 2018.12.01.)

- Fisher, Mark: Capitalist Realism. Zero Books, London, 2009.

- Frasca, Gonzalo: Szimuláció vs. narratíva - Bevezetés a ludológiába. In: Fenyvesi Kristóf - Kiss Miklós (szerk.): Narratívák 7. - Elbeszélés, játék és szimuláció a digitális médiában. Kijárat Kiadó, Budapest, 2008. 125-142.

- Frasca, Gonzalo: The Sims: Grandmothers are cooler than trolls. Game Studies, 2001. július, 1/1. sz. URL: http://www.gamestudies.org/0101/frasca/ (Letöltés ideje: 2018.12.01.)

- Frasca, Gonzalo: Videogames of the Opressed: Videogames as a Means for Critical Thinking and Debate. Ludology.org, 2001. URL: http://www.ludology.org/articles/thesis/FrascaThesisVideogames.pdf 
(Letöltés ideje: 2018.12.01.)

- Friedman, Ted: The Semiotics of Sim City. First Monday, 4. évf. 4. sz., 1999. április. URL: http://firstmonday.org/ojs/index.php/fm/article/view/660/575 (Letöltés ideje: 2018.12.01.)

- Frye, Northrop: A kritika anatómiája. Helikon, Budapest, 1998.

- Gerencsér Péter: myContent.swf - A Flash-esztétika diskurzusai. Médiakutató, 2016. XVI. évf. 2. szám, 29-40.

- Haider Edit: A libajátéktól a Monopolyig - A lépegetố társasjátékok történetérôl. Sic Itur ad Astra, 2013. 63. sz., 25-34.

- Juul, Jesper: Fear of Failing? - The Many Meanings of Difficulty in Videogames. In: Perron, Bernard - Wolf, Mark J. P.: The Video Game Theory Reader 2. Routledge, New York/London, 2009. 237-252.

- Juul, Jesper: Games Telling stories? - A brief note on games and narratives. Game Studies, 2001. július, 1/1. sz. URL: http://www.gamestudies.org/0101/juul-gts/ (Letöltés ideje: 2018.12.01.)

- Kapelner Zsolt: Ôrzôi vagyunk-e a természetnek? a szem, 2017. URL: http://aszem.info/2017/07/orzoi-vagyunk-e-a-termeszetnek/ (Letöltés ideje: 2018.12.01.)

- Kinder, Marsha: Playing with power in movies, television, and video games: from Muppet Babies to Teenage Mutant Ninja Turtles. University of California Press, Berkeley, 1991.

- Kisantal Tamás: Játsszunk történelmet! - A számítógépes játékok történelemkoncepciói. Sic Itur ad Astra, 2013. 63. sz., 193-212.

- Kiss Gábor Zoltán: A részvétel módjai és a rövidformák - Folytatásos regények, epizódok és tévésorozatok. In: Thomka Beáta (szerk.): Befejezetlen könyv. Kijárat Kiadó, Budapest, 2012. 251-263.

- Kiss Gábor Zoltán: Efemer galériák - Videojátékok kritikai megközelitésben. Gondolat, Budapest/Pécs, 2013.

- Konzack, Lars: Philosophical Game Design. In: Perron, Bernard - Wolf, Mark J. P.: The Video Game Theory Reader 2. Routledge, New York/London, 2009. 33-44.

- Marcelli, Miroslav: A Barthes-példa. Kalligram, Pozsony, 2011.

- Morton, Timothy: Ecology after Capitalism. Polygraph, 2010. 22. sz., 46-59.

- Morton, Timothy: Ecology Without Nature - Rethinking Environmental Aesthetics. Harvard University Press, Cambridge/London, 2009.

- Murray, Janet H.: Hamlet on the Holodeck: The Future of Narrative in Cyberspace. The Free Press, New York, 1997.

- Nagle, Angela: Kill All Normies. Zero Books, Winchester/Washington, 2017. 19-27.

- Newman, James A.: Best Before: Videogames, Supersession and Obsolescence. Routledge, London/New York, 2012. https://doi.org/10.4324/9780203144268

- Orbanes, Philip: Monopoly: The World's Most Famous Game - And How it Got that Way. Da Capo Press, Cambridge, 2006.

- Pobłocki, Kacper: Becoming-state - The Bio-cultural Imperialism of Sid Meier's Civilization. Focaal - European Journal of Anthropology, 2002. 39. sz., 163-177.

- Provenzo, Eugene F.: Video Kids: Making Sense of Nintendo. Harvard University Press, Cambridge, 1991. https://doi.org/10.4159/harvard.9780674422483

- Raley, Rita: Tactical Media. University of Minnesota Press, Minneapolis/London, 2009. 
- Rancière, Jacques: A felszabadult nézó. Múcsarnok Kiadó, Budapest, 2011.

- Sartre, Jean-Paul: Mi az irodalom? Gondolat, Budapest, 1969.

- Schrank, Brian: Avant-garde Videogames - Playing with Technoculture. MIT Press, Massachusetts, 2014.

https://doi.org/10.7551/mitpress/8132.001.0001

- Sicart, Miguel: Family Values: Ideology, Computer Games \& The Sims. DIGRA Digital Library. URL: http://www.digra.org/wp-content/uploads/digital-library/05150.09529.pdf (Letöltés ideje: 2018.12.01.).

- Stam, Robert: Reflexivity in Film and Literature - From Don Quixote to Jean-Luc Godard. Columbia University Press, New York, 1992. 212.

- Vogel, Steven: Environmental Philosophy after the End of Nature. Environmental Ethics, 2002. 24/1., 23-39. https://doi.org/10.5840/enviroethics200224139

- Weber, Max: A protestáns etika és a kapitalizmus szelleme. Gondolat, Budapest, 1982.

- Wolf, Mark J. P. - Perron, Bernard (szerk.): The Routledge Companion to Video Game Studies. Routledge, New York/London, 2014. 442-450.

- Žižek, Slavoj: Censorship Today: Violence, or Ecology as a New Opium for the Masses. Lacan.com, URL: http://www.lacan.com/zizecologyl.htm (Letöltés ideje: 2018.12.01.) 
(C) Apertúra, 2019. tél | www.apertura.hu

webcím: https://www.apertura.hu/2019/tel/andras-elkotelezett-jatekok/

https://doi.org/10.31176/apertura.2019.14.2.6

Apertura.hu

Image not found or type unknown 